\title{
4 Crossing the bog
}

\section{Mossbawn}

Mossbawn is the name of Seamus Heaney's family home: a farm in Co. Derry, located at the edge of bogland near Lough Beg (Heaney 1980). Though 'bawn' is the anglicised word for a cattle enclosure, the notion of his being 'moss-born' seems fitting. Of the bogs he once said, 'It is as if I am betrothed to them', remembering an earthy 'initiation' of swimming in a moss hole, from which he emerged steeped in the peat, marked from then on by 'this hankering for the underground side of things' (Heaney 2002: 5-6). If the iconic work by Glob ([1969] 1971) brought the bog bodies into the public light, Heaney's poems magnified their meaning, giving them a contemporary resonance. Yet those poems also made people look again at the bog landscape. Heaney brought a dwelling eye to the place, making us see them again, not as a marginal landscape or cultural backwater, but as the place he was born and brought up: an omphalos, the navel of the world that surrounded it (Heaney 2002: 1). He did not shy away from their dangers but showed how such fear could be mobilised in the cultural imagination, while also bringing to light its riches and treasures. This chapter attempts to achieve the same re-envisioning of the bog, through palaeoenvironmental, archaeological and archival evidence.

\section{The bog, the moss, the mire and the moor}

Peat forms under waterlogged conditions where plant matter grows faster than it can decay, due to an oxygen-excluding environment that slows the normal breakdown of organic matter (van der Sanden 1996: 21). Highly humified peat contains well-decomposed plant matter that has created a dark-brown, blackish amorphous mass, but where plant remains are still identifiable it is described as poorly humified (van der Sanden 1996: 21). Peat can grow at variable rates: Godwin ([1981] 2009) records $6 \mathrm{~cm}$ per century at Scaleby Moss (Cumbria) compared with $3.3 \mathrm{~cm}$ 
at Red Moss (Lancashire), within the UK. Bog peat growth in north-western Europe began around $5000 \mathrm{BC}$, coinciding with the onset of higher rainfall and more humid conditions known as the 'Atlantic' phase. Wetter phases after this threshold (notoriously a climatic downturn in the later Bronze Age and early Iron Age) have exacerbated both bog growth and human reactions to it (Godwin [1981] 2009), but these are complicated in later prehistory by local variation. Topography, drainage, vegetation cycles, land ownership and agricultural histories must all be considered on a case-by-case basis, which require detailed investigation (Chapman and Gearey 2013). In order to understand the contexts of bog bodies, we must first draw a distinction between the two main types of peat formation: fen and bog peat.

Fen peat develops in contact with groundwater, and continues to be fed by inorganic minerals from the surrounding subsoil, thus being known as 'minerotrophic' (Chapman and Gearey 2013) or 'eutrophic' (Godwin [1981] 2009: 5). It tends to form in a damp depression, being heavily determined by the local microtopography. Plant matter dies and falls in at its edges, creating a stagnant pool of water in the centre with a recognised hydrosere - a progression of plant colonisation and growth (Godwin [1981] 2009: 4). These environments are initially characterised by sedges, reeds and some bulrushes, while the growth of peat begins to permit shrubs such as sallow, hairy birch and alder to colonise, developing into fen woods with alder, oak and ash joining the smaller tree cover (Godwin [1981] 2009: 4). Low-lying, constantly flooded areas such as this are often described not just as fens but mires; they are often alkaline, due to the influence of calcareous groundwater but certain local rock formations can produce acidic fen peats (Godwin [1981] 2009: 5). As they grow, such hollows can become completely filled with plant remains. If the centre of this fen peat becomes completely cut off from the surrounding groundwater, it can be transformed into a 'raised bog', creating a lenticular appearance.

Bog peat meanwhile is more climate dependent: it only forms in areas of high rainfall and is sustained by rain or snowfall with low mineral content (Godwin [1981] 2009: 6). They are thus known as 'oligotrophic' (Godwin [1981] 2009: 6) or 'ombrotropic' bogs (van der Sanden 1996: 22) and since they lack the ameliorating effect of any carbonate-rich groundwater are exclusively acidic. Only certain types of plants can tolerate the nutrient-poor environment, principally bog mosses (Sphagna). These plants are formed of a main stem with smaller branches and a tightly formed head (a capitulum, see Laine et al. 2018). Their large, empty porous cells are designed to act as a sponge: conveying water to the chlorophyllous cells that initiate photosynthetic activity, enabling the plant to grow autonomously (Godwin [1981] 2009: 69). Such plants can retain up to twenty times their own weight in water, meaning that bogs can be composed of 95 per cent water (Aldhouse-Green 2016). Long slender leaf forms tend to favour very wet conditions, living at the edge or just under the water, whereas broader leaf species form the denser masses known as 'moss lawns'. Those with very small leaves often rise 
above the water table to form hummocks. Dying moss matter sinks below this independent water level, allowing the moss to grow higher than the surrounding terrain, swelling to encroach over land at its edge. At this stage, the raised bog is like a huge blister of partially decomposed plant matter and fluid, held tentatively together by living moss (van der Sanden 1996: 22) and performing, in Robinson's (2007: 29-30) memorable words a 'slow self-inhumation and self-resurrection'. Edgeworth (2011) has used the notion of water as the unseen 'dark matter' of the landscape, but here it assumes a new meaning in relation to the bog, whose watery nature is hidden by being infused in moss and peat. Godwin ([1981] 2009: 8) cautions against describing its epicentre as a cupola or dome since it is almost flat van der Sanden (1996) prefers the word 'lens', a landscape feature we will return to (Figures 4.1a and 4.1b). At its margins, small steep slopes (known as 'rands') may be cut by drainage streams, while in its midst, open, dark-brown pools form within the moss (van der Sanden 1996: 22). These pools are bare of vegetation and framed by hummock-building colonisers such as the 'crimson' mosses of Sphagnum magellanicum, S. rubellum and S. Plumulosum that gave rise to the local name of the 'red bog' (van der Sanden 1996: 22). The hummocks themselves can span several metres, rising 10-20 cm above wetter hollows and spanning 1-10 m (van der Sanden 1996: 25). This is the classic landscape of the Atlantic raised bog found in Ireland, Britain, the Netherlands, Germany and some of Norway (van der Sanden 1996: 25). Van der Sanden (1996) compares this with the Baltic or concentric raised bogs more characteristic of Denmark, Poland, southern Sweden and south-west Finland.

The raised bog (Figures 4.1a and 4.1b) can also be contrasted with the 'blanket bog' (both of mountainous and lowland type) found in Ireland and Britain, where there are more extreme oceanic conditions and higher rainfall. Blanket bog can accumulate on slopes of up to $25^{\circ}$ as well as flat surfaces, in such wet climates to create an almost continuous 'mantle of mire' (Godwin [1981] 2009: 11). Within these blankets of peat, there can exist many localised features, such as perched or dammed lakes and pools - Robinson (2007: 24) counts more than a hundred in the 25-30 square mile radius of Roundstone bog, many of which have their own names and stories attached to them. Since drainage on these slopes is impeded by the peat, it is only slightly eutrophic, and can lead to the creation of 'acid fens' (which may help to explain the discovery of many well-preserved bog bodies from the Highlands and Islands of Scotland, for example). Further types of bogland are found in fenland-type 'aapa' bogs of central Norway and Sweden, Finland and some areas of Russia; the 'palsa' bogs lying north of the Arctic circle, forming over permafrost; and the Continental or woodland bogs of north-east Poland and central-European Russia (Robinson 2007: 25). However, most of the archaeological remains discussed in this volume, following van der Sanden (1996), come from the Atlantic raised and blanket bogs. 


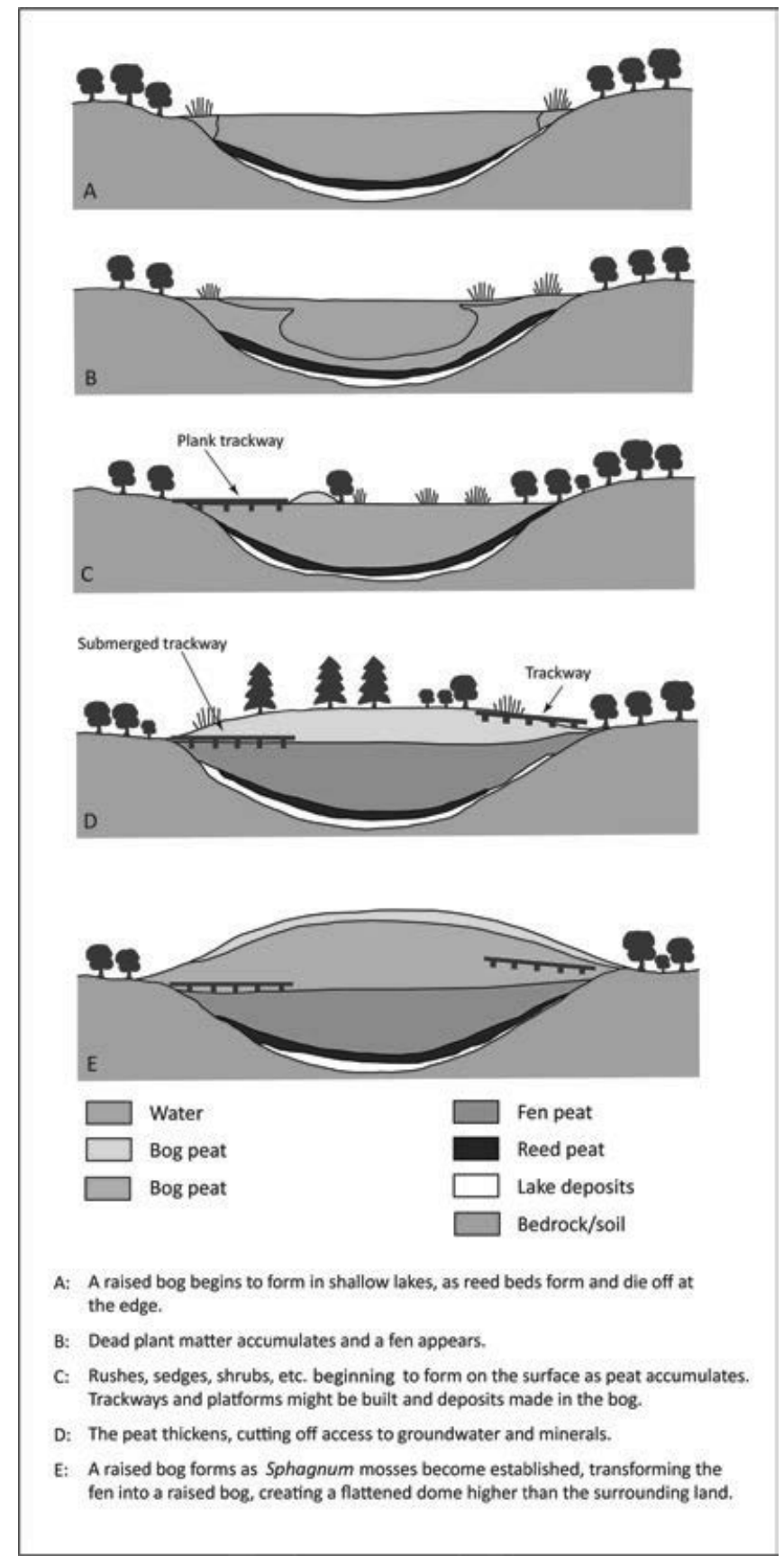

4. I a The formation of a raised bog. 


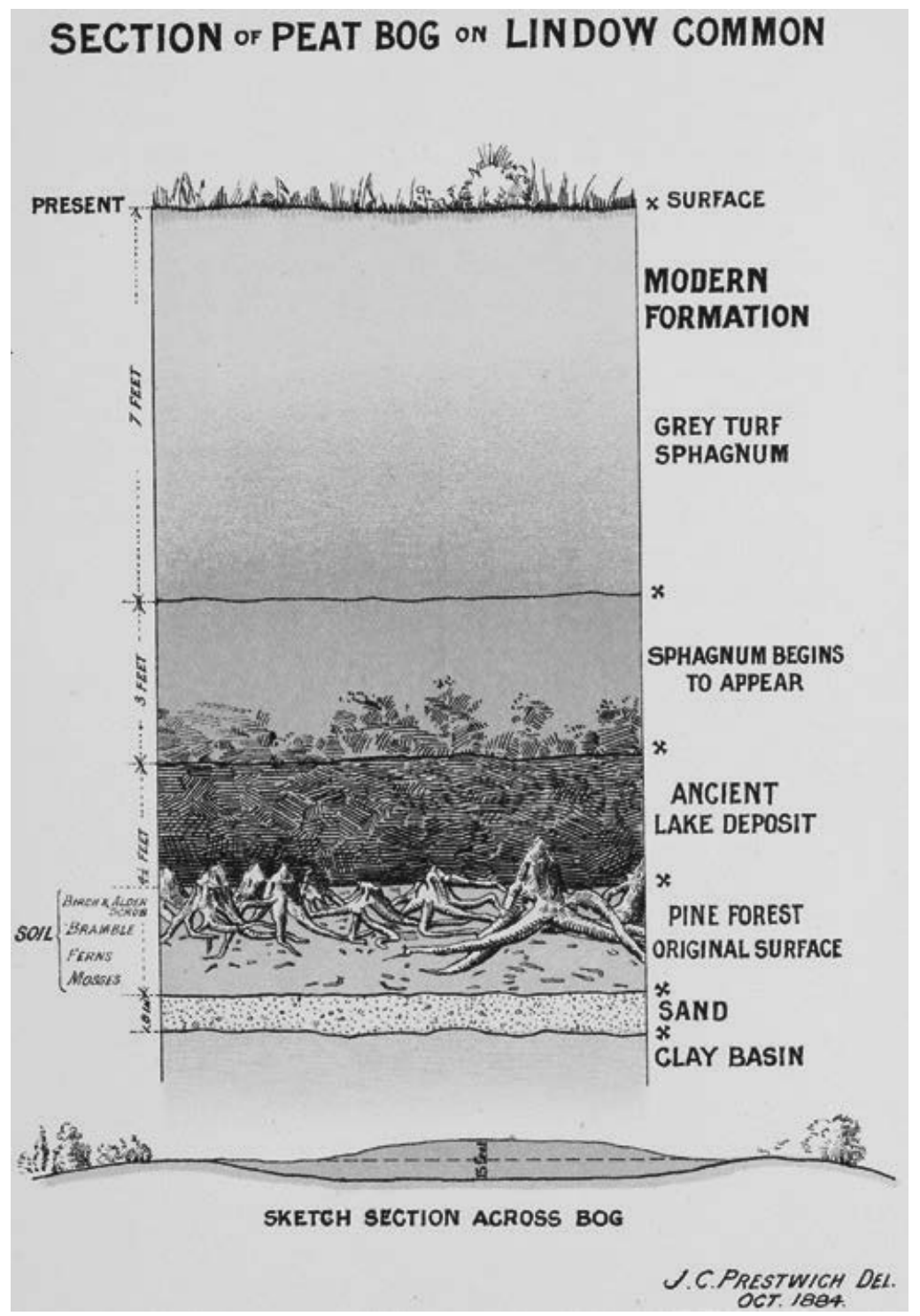

4.Ib 1884 section through Lindow Moss bog. All rights reserved and permission to use the figure must be obtained from the copyright holder.

\section{The later prehistoric landscape of the bog}

It is worth now situating ourselves more firmly within the environmental history of these bogs during the key period in question: the first millennium BC 
to early first millennium AD. Godwin ([1981] 2009) famously described these deep accumulations as 'archives of the peat', containing records not just of climate and vegetational change, but as we shall see in Chapter 7, fuel exploitation, mineral extraction and chemical exploitation histories (e.g. Le Roux et al. 2004; Rotherham 2009). Across northern Europe, a general climatic downturn towards the end of the Bronze Age brought wetter and cooler conditions that enhanced the growth of upland blanket bog, raised bog and lowland mire alike (Godwin 1975; Houghton et al. 1996; Mauquoy et al. 2002, 2004; Barber 2006). The reasons for this are complex but probably involve a mix of what is called 'solar forcing' coupled with shifts in ocean circulation west of the UK (Brown 2008). Integrated environmental analysis, using pollen records, testate amoeba (as indicators of bog surface wetness - henceforth BSW), records of peat humification and macrofossil analysis (especially of Sphagnum spp.) provide a rich insight into the scale and chronology of its impact (e.g. Barber et al. 2000; Tipping 2015). In Britain, a general pulse of wetter conditions is noted from around $1500 \mathrm{BC}$ for around two hundred to four hundred years before slightly drier conditions take hold (Brown 2008). A key threshold appears to be the late Bronze Age to early Iron Age transition, c.800-750 cal BC, when BSW increases across Europe in what was 'probably the most profound climatic shift in the Holocene prior to the Little Ice Age' (Brown 2008: 8; see also Mayewski et al. 2004). In Tipping's (2015: 103 and 110) words, the rapidity of such changes could be 'abrupt, perhaps complete in decades and certainly noticeable to human populations and of sufficient scale to impact on societies', but he also cautions against seeing its effects as a 'pell-mell' retreat from the uplands and socio-economic panic. More rational reappraisals of what grew best and where seems to better characterise some areas of continuity and other examples of shifting settlement and new emphasis on crops or stock as appropriate, but he notes the most intense experience of these changes would have been felt in the lowlands (Tipping 2015). Another increase in this surface wetness of bogs occurs around $400 \mathrm{BC}$ before drier and warmer climates that characterised the early Roman period in the UK/later Iron Age in those countries not invaded by Rome. Using dendrochronological evidence and ice-core records, Baillie and Brown (2013: 64, tab. 3) have argued that we can also see particular stress on the environment precipitated by volcanic activity, reflected in poor tree-ring growth in Ireland and England around $207 \mathrm{BC}$, with further low seasons of growth around 52-48 BC and a severe volcanic event commencing c.44 BC. In southern England, this decade was marked by the rippling impact of Caesar's success in Gaul and attempt to conquer Britain. Environmental and historical events must have collided to make this a stressful time of change in many domains of life - a point to which we will return in Chapter 7 .

Each region and country had its own particular experience of these changes. However, the impact upon later prehistoric communities living close to or within wetlands would have been disproportionate compared with more dryland zones. The Iron Age gallery in Moesgaard Museum, Denmark, introduces visitors to this in a novel way: delicate steel rods suspended from the ceiling glitter with a play 
of light that makes it seem as if persistent rain is falling. The gallery floor under the visitor's feet is suddenly soft and wobbles slightly - disconcerting the visitor, using a clever medium of rubberised flooring to mimic the infirm surface of the bog. A written panel makes the simple point that during the early Iron Age, 20 per cent of the land was peat bog; its growth swallowed large volumes of cultivatable land (Asingh and Lynnerup 2007: 276). Settlement retreated and drew up on to higher lands and exposed knolls. Arable cultivation may have disappeared from some areas - many of the Irish bogs show little evidence of cultivation in the near vicinity for instance (McDermott et al. 2009). In other areas, farming may have intensified on surviving soils, depleting fertility and requiring innovation and expansion into new areas. Clearance of previously wooded or regenerated areas can be seen in some locales, while others placed a renewed emphasis upon pastoralism.

At Toar bog in Ireland, where a magnificent large alder tub known as the 'Pallasboy vessel' was deposited, the surrounding landscape shows little evidence of nearby inhabitation (McDermott et al. 2009: 60), yet not far away, in the Cloneal bog where Old Croghan Man was found, a multi-proxy study showed that the clearance of regenerated woodland had begun again around the time of his death, c.300-200 BC, associated with the development of bog pools (Plunkett et al. 2009: 275). In England, the same encroachment of the peat over field systems and rising of the waters can be seen in the late Bronze Age/early Iron Age Flag Fen landscape (Pryor 2005). In the wetlands of Cheshire, Lancashire and Greater Manchester the expansion of the upland blanket peat as well as lowland bogs is seen from $c .1700-1400$ BC onwards, with the establishment of a complex mire system by the Iron Age (Middleton et al. 1995; Middleton et al. 2013; Leah et al. 1997). Woodland clearance is seen in the pollen records for Lindow Moss in the early Iron Age (Branch and Scaife cited in Stead et al. 1986), probably to support pastoral-based agriculture, but regeneration of the woodland cover then characterises the next few centuries, fitting in with evidence from Ashton Moss of a much wetter period of peat development $c .600 \mathrm{BC}$ and little by way of human activity nearby (Nevell 1999). On Lindow, clearance starts again c.340 cal BC, with slight traces of cereal cultivation (wheat, barley, oats, hemp or hops), some evidence for burning activity yet 'little settlement and agriculture in and around the mosslands' themselves (Timberlake and Prag 2005: 16-17). Indeed, by the time of Lindow Man's death (the remains otherwise known as Lindow II, see Joy 2009), increased surface wetness on the bog itself was evidenced by peat macrofossils and insect evidence, suggesting it had been transformed from a wet 'spongy' surface into one on 'widespread pools full of aquatic moss ... very difficult to walk upon ... without getting wet and ... sinking in to knee-depth' (Barber cited in Stead et al. 1986: 89).

Why does a micro-environmental study of the location of bog body deposition matter? As Chapman (2015) as argued, whether this was a vast expanse of moss, the carpet like-covering of a quaking bog, a discrete, small 'cauldron' bog, an area of open lake within a moss or the black pupil of a seemingly bottomless pool, these provided very different kinds of places in which to inter a body. 
Haraldskaer Woman, for example, was positioned over a spring erupting from the bog (Aldhouse-Green 2016: 33). From a lack of cadaverous insect species and flies, we know that the Lindow II body was swiftly covered by immersion in a bog pool (Buckland 1995: 50). Barber (1995: 51) considers this to have been a wide but essentially shallow feature, where 'felted pool peat' might have been cut and rolled back to insert the body, literally 'covering up' the evidence and leaving no trace in the overlying stratigraphy. Yet water beetles and plant-eating species suggesting it was fringed with reeds and sedges, forming a notable, if rather stagnant, pool (Girling cited in Stead et al. 1986: 90). Integrating later borehole data from the North-West Wetlands Survey (NWWS) with digital terrain modelling, however, Chapman (2015: 117) was able to show that all of the Lindow remains but most particularly Lindow II were deposited in the deeper parts of the bog: 'as far from contemporaneous dryland as was possible. This might help explain the discrepancy in radiocarbon dates noted for Lindow II that led some to question whether bog bodies could be dated at all (Briggs 1995). The peat in which Lindow Man lay yielded an early to mid-Iron Age date (c.700-200 BC), but the human remains themselves seem to indicate death and deposition centred on the first century AD (Gowlett et al. cited in Stead et al. 1986; Housley et al. 1995). This discrepancy in dates was also the case with Zweeloo Woman from the Netherlands, and in her case, it was assumed that she lay in a dug grave or pit that left no trace in the bog stratigraphy (van der Sanden 1996: 97). Such pits had clearly been dug into the bog where both Windeby Man and Windeby Boy (once thought to be a young girl) were also deposited and 'staked' down (van der Sanden 1996: 98). There is still much to resolve with radiocarbon dates from the bog. Godwin ([1981] 2009: 161) and van der Plicht et al. (2004) acknowledge the danger of absorption of carbon atoms from the peat water, which might produce a date that is 'too old' for the body, or obversely, contamination from 'new peat' as younger materials invade human remains as rootlets or humic material in solution, effectively giving a younger date than that of the original deposition. However, the extensive dating programme by van der Plicht et al. (2004) provides good evidence that with correct sampling and pretreatment, unconserved remains can yield reliable dates.

The current agreement then is that sometime during the early occupation of Roman Britain, Lindow Man himself or his remains were brought across a 'potentially treacherous, waterlogged land surface' (Chapman 2015: 117). The bog pool into which he was lowered was a black pit, like the open lens of an eye: still, reflective but unblinking. It may have been a natural feature or even an old, waterfilled peat cutting, but either way, it meant that he sank on to a layer of peat laid down centuries earlier. From the stratigraphic section of the bog (Stead et al. 1986: fig. 4.2) the pool itself may not have been very deep despite overlying the furthest and presumably the highest point of the mire (see Norbury 1885: 62). The jeopardy involved in this crossing may have been part of the performative challenge of the event, making this less of a bogside public spectacle and more of a restricted act, undertaken with some risk to the perpetrators in the depths of the moss, where its hummocks intersected with deep pools. The small party may have 
been visible in silhouette, magnified against the horizon as they made their tricky journey across the bog.

Such risk may have been necessary if total immersion in an almost inaccessible locale was part of a thanatological solution, disposing of either the 'dangerous dead' (achieving a proper and fitting end to this life, see Giles 2016) or to make offerings in a place where the supernatural realm could be met with (van der Sanden 1996: 174). Eliade (1963, cited in Bradley 2017: 188) described such places as heirophanies - 'places where the sacred showed itself'. The bog pool was palpably different to other kinds of water bodies: here there was no flow, no generative fluidity of river, spring or stream, just the black hole of the peat pool itself (see Edgeworth 2011). These performative dimensions and exact locales matter, as Fredengren (2015) has argued. They are part of the 'water politics' through which people negotiated their relationship with fluid media such as rivers and lakes, yet the bog combined all the power of such water worlds with a place that was feared to be literally fathomless. Bogs were particularly troublesome in the first millennium BC - in flux and capable of intervening in the human world in violent ways. This might explain why some bogs attracted repeat depositions such as Tolland Man and Elling Woman, found a mere 60-70 m apart; the three individuals from Borremose; two from Windeby; three from Damendorf; and four from Bourtangermoor (van der Sanden 1996: 103). Lindow itself has at least two if not three interments (Joy 2009). As well as multiple human remains, some bogs attracted human depositions alongside concentrations of other objects Rappendam for example, where a female bog body was found close to both animal remains and wheel, wagon and agricultural tool fragments (see Chapter 5). In sum, this history of environmental change and hydrological dynamics is the background against which more individual landscape stories of bog bodies must unfold (Chapman 2015). Next, we turn to the evidence for how this access to the bog itself might have been managed and experienced.

\section{Trying to cross the 'roulling moss': bog trackways}

That the bog grew was widely known - landmarks that might once have been visible across a bog could disappear within a generation, as in the case of Crowle Church, which was gradually obscured from view in Thorne as this mire in South Yorkshire expanded (Parson 1877). Bog growth also had a seasonal dimension to it, as Higson (1859: 119) warned in relation to the Droylsden Moss (Lancashire): 'the peat in wet seasons swells out, like a sponge, diminishing the prospect until the moisture gradually subsides'. Yet he also noted that on the Lancashire bogs, as they were increasingly drained and cut for fuel, 'objects concealed from certain standpoints ... are constantly becoming more and more visible' (Higson 1859: 119). The waxing and waning of the bog warned local inhabitants of their mercurial animacy, captured in a British folkloric 'typology': the most fluid underfoot were 'quaking' (King 1685: 949) or 'shaking' bogs (Butterworth 1842: 120), difficult 
to traverse. When someone steps upon such a 'quag' moss, Walker (1772: 124) warned, 'it bends in waves under his feet; and if the surface breaks, he is danger of sinking to the bottom'. Yet on Ashton Moss, Butterworth (1823: 87) commented that the local people were so 'tenacious' they 'venture[d] to cross it in any season'.

This was not an easy task and each community and era dealt with its challenges in different ways. The tussle between turf cutting and drainage in post-medieval Lancashire and Cheshire created a new problem of larger-scale drains, in addition to the natural undulations of bog pool and hummock. Their response was the installation of 'plattings' (small bridges made of logs, and sometimes, stones) laid down to enable people to cross the ditches and cut their turf (Bowman 1960: 46). These features can be seen on a remarkable map of Wyatt Moss in Lancashire, dated 1571 (Figure 4.2), and discussed by Shannon (2015) in relation to turbary (peat-cutting) rights. The illustration shows the bog at the cusp of change: eaten away at its edges by improved land under cultivation and fringed with a rim of course pasture, successfully drained. Then, towards the centre of the bog, the hard boundaries stop: there is a ring of small, parallel plots known colloquially as 'moss rooms', laid in rows, where the bog was now being allotted by the manorial lord to certain tenants. These surround a central area of untouched mire. Back in Ashton, Bowman (1960: 46) records that access to such moss rooms was further

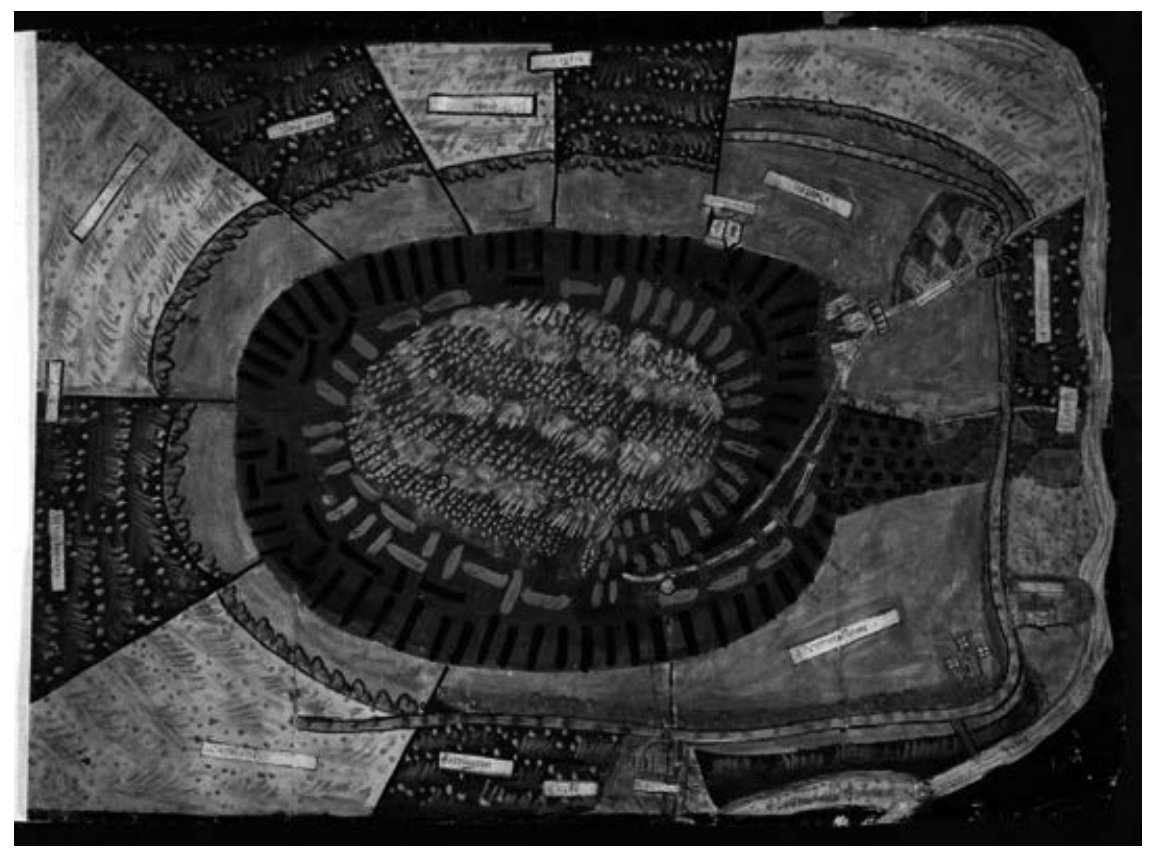

4.2 Wyatt Moss I57I, showing the small 'platts' (bridges') and to the east, the deep pits known as the 'hell holes'. All rights reserved and permission to use the figure must be obtained from the copyright holder. 
controlled by narrow lanes (called 'gates') and hinged gates (confusingly known as 'yates'), while the otherwise featureless parish boundary with Droylsden was marked 'by long oaken poles, fixed upright at distances from twenty to thirty yards apart' (Higson 1859: 10-11). By the sixteenth and seventeenth centuries, rights to cut peat were controlled by either rent or costs-in-kind to the local manorial lord, such as 'ten cartloads of turves to Asheton' (the manor house) by every tenant (Bowman 1960: 46). Understandably, this required an infrastructure that allowed hand- or horse-drawn carts to cross in and out of the moss. On the Wyatt map, these little bridges or 'plattings' are faithfully recorded crossing the wet ditches and a stream that fed a water mill. Wet weather further exacerbated these crossings: special 'winter-ways' or 'winter-gates' allowed the residents of Ashton to pass over private fields to get to the moss, if their customary lanes were flooded or snowed in (Bowman 1960: 345).

These crossings have their counterparts in prehistory, ranging from small brushwood bundles used to stabilise a land surface, to raised walkways, laid tracks and more massive pieces of construction known as 'corduroy' roads. Antiquarian records have been swelled by the 'rescue' and developer-funded archaeology that accompanied mass peat extraction in the later twentieth century (such as the work of the Irish Archaeological Wetland Unit) and research-led surveys across the northern European wetlands. A few examples will help conjure the character of these paths, which can seldom be directly related to the deposition of bog bodies, but provide wider evidence for activity within such bogs.

In Ireland, laid roundwood or brushwood bundles form 'toghers' (tóchairs), which would support 'pedestrians or animals', while more 'finely woven hurdle panels were used to create narrow later Bronze Age and Iron Age trackways (Moore et al. 2003). At Edercloon, a remarkable complex of tracks was associated with fragments of everyday objects: bowls, an alder tub, an un-used mallet, wheel fragments and two yew-spear shafts (McDermott et al. 2009: 56-7). In Derryville bog, trackway Killoran 18 (a brushwood and stone causeway) has been dated to the middle Bronze Age, whereas a hurdle track crossing a very wet area of bog pools dates to $280 \mathrm{cal} \mathrm{BC}$ (Caseldine and Gearey 2005: 598). The Derraghan More track (investigated by Rynne in the 1950s) and the magnificent Corlea trackway excavated by Raftery in the 1980s (Raftery 1996; McDermott et al. 2009) are at the most impressive end of the scale. Both were constructed in the middle Iron Age, focused on felling dates of 159+/-9 BC for Derraghan and 148-7 BC for Corlea (McDermott and Moore 2010: 3; see Figure 4.3). In the former bog, large oak planks were laid over a foundation of brushwood and lengths of roundwood; this construction method was paralleled at Corlea, where in a single season of massive labour over four hundred mature oak trees were felled along 25 ha of mixed woodland (McDermott and Moore 2010: 3). Over six thousand oak planks laid on longitudinal runners were pegged in place, with additional brushwood used to soak up especially boggy areas (Raftery 1996). These two larger tracks traverse the bog to connect dryland islands. From pollen records, the tracks appear to have been built towards the end of a four hundred-year period of woodland clearance, 


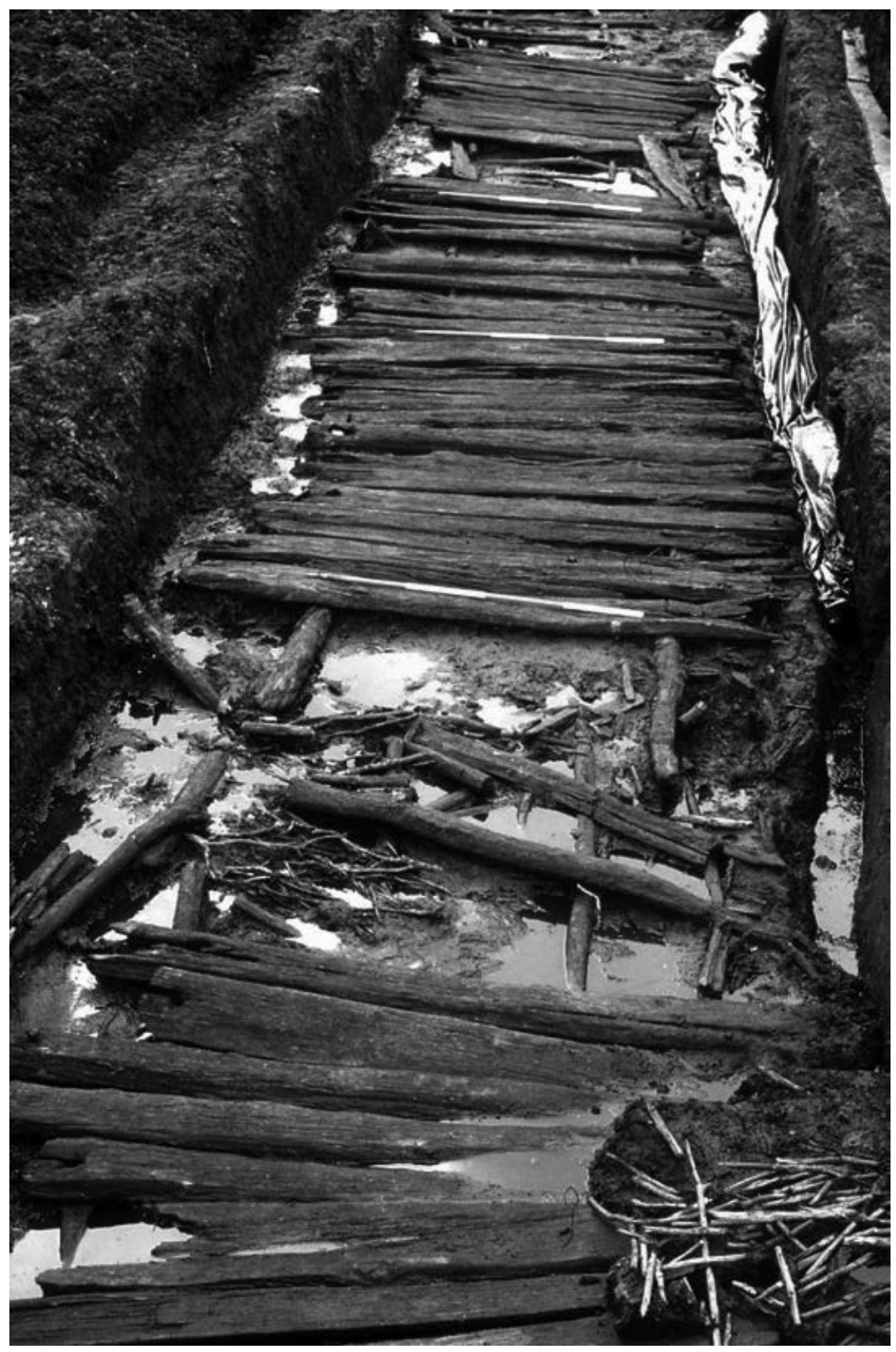

4.3 The Corlea trackway, excavated by Professor Barry Raftery, University College Dublin. All rights reserved and permission to use the figure must be obtained from the copyright holder. 
although evidence for farming in the area is slight (McDermott et al. 2009: 57). Yet Corlea may have only lasted a decade above the bog surface: repairs and areas of burning and dismantlement suggest a short-lived, 'eventful life' before it was subsumed by rising peat (McDermott and Moore 2010: 4). This track could have supported wheeled vehicles, as cart or chariot fragments were found among the trackway deposits, alongside a wooden mallet, bucket staves, handles and an apparent 'tent peg' (Coles and Coles 1989: 159). Raftery (1994) himself famously called this 'the road to nowhere', forcing archaeologists to rethink the purpose of these tracks. As McDermott and Moore (2010: 5) point out in the example of Edercloon bog, some trackways skirt the dryland edges, as if teetering on the brink of the wet, while others change tack to intersect with neighbouring paths and platform areas, creating intersections, meeting or gathering points for communities coming from different directions. They suggest a crossing over and into the bog and its small networks of raised islands: an investment of labour, skill and prowess, which tells us the moss was an important place of interaction, to be visited and engaged with.

Trackways in Denmark and Germany help us understand why this might have been needed. The construction at Bjældskovdal bog consisted of rows of vertical oak posts, possibly supporting a slightly raised track, dated to the early Iron Age (700-600 BC) (Fischer 2012: 98). It fitted into a network of similar tracks crossing and circuiting nearby bogs, such as the Speghøge Mose trackway (Fischer 2012: 98). These tracks are of interest due to their proximity to Tollund Man and Elling Woman, and Fischer (2012: 99) interpreted them as a network enabling access into the bog to cut peat, the old hollows of which had been selected as the appropriate place in which to inter these hanged individuals. In contrast to these timber trackways, a more monumental stone surface was laid across the Tiburke bog around 200 BC, creating a $3 \mathrm{~m}$ paved road (Coles and Coles 1989: 162).

Woven-hurdle, raft-like paths and more substantial plank-built trackways dating to the Bronze Age and Iron Age have been found at Bourtangemoor in Germany, which did not cross from ridge to ridge but seem to focus on entering the bog, perhaps to obtain iron ore (Coles and Coles 1989: 163). An iron punch was found on one of the tracks, and an associated nearby settlement at Angelsoo was the site for household-based ironworking (Coles and Coles 1989: 163). These contrast with a suite of paths on the Grosse Moor am Dümmer, where multiple oak trackways criss-cross the narrowest passage between drylands, spanning a $2 \mathrm{~km}$ wide stretch of bog. Wooden shovels, mallets and vehicle components were found on the Whittemoor Bohlenweg III track among this Iron Age complex, dating to 640 BC, with intriguing decorated planks (marked by their makers?) found on a nearby track dating to 713 BC (Coles and Coles 1989: 166). Next to the tracks were an intriguing series of figures, which we will return to in Chapter 5.

In Britain, over 182 wetland wooden prehistoric trackways are known (Brunning 2007), though many of these are located in the Somerset levels (Coles and Coles 1989), estuarine/inter-tidal locations (Bell et al. 2000) or river edges (such as Flag Fen, see Pryor 2005; and Fiskerton, see Field and Parker Pearson 
2003). The Cambridgeshire Fens have also revealed some astonishing riveredge activity, such as late Bronze Age middens and a shrine complex at the Over Narrows, involving the deposition of human bone/body part offerings and bird sacrifice (Evans et al. 2016). A middle to late Bronze Age trackway was found across a stretch of Thorne Moors on the Hatfield levels, consisting of up to seven split and laid timbers (some charred, lacking their bark) spanning $3 \mathrm{~m}$ across (Buckland 1979: 14; Chapman and Gearey 2013: fig. 2.16). Another trackway was reported on Hatfield Moor by a farmer, while a late Neolithic trackway and structure was sampled north of Lindholme Island (Chapman and Gearey 2013: 28). Through environmental analysis and landscape modelling, Chapman and Gearey (2013: 35) have shown that during the later Bronze Age to early Iron Age, surface wetness made the Thorne and Hatfield Moors increasingly treacherous and difficult to cross. Meanwhile, in the Humberhead levels, a late Bronze Age feature at West Furze (originally interpreted as a lake dwelling or crannog) has been reinterpreted by van der Noort (1995: 332-3) as a two-phase trackway or crossing point at the narrowest neck of the Low Mere. The early brushwood platform was overlain by a more monumental series of horizontal tree trunks, further overlain by a layer of sand and lighter-weight twigs, bark and branches. Small piles or stakes pegged the major timbers in place, but a row of further uprights suggests that overall this was a refurbished or temporarily occupied part of an older causeway, with a 'wicket-' style entrance gate that may have formed not just a practical but symbolic entrance to a network of fen carr (van der Noort 1995: 326, 334). Flint, perforated stone, pottery, at least three human skulls and an apparently articulated human hand were found at West Furze, along with a bronze spearhead (van der Noort 1995: 326). In Lancashire, the system of small tracks known as Kate's Pad, crossing Pilling Moss, seem to consist of at least three different trackways, dating to the early/mid Bronze Age (Innes et al. 2010). On the Mobberley side of Lindow Moss a wooden trackway was found in the nineteenth century: 'a roadway made of logs of timber placed end to end, with sleepers across laid close together, and this I am told continued for some length up the Moss, and I think it was at the bottom of the bog' (Norbury 1885: 65). The construction and stratigraphic location support a prehistoric date and the nearby remains of a 'decomposed skeleton of a wild boar' on the Lower Moss at Mobberley indicates the wealth of local game, tempted or driven on to the moss (Norbury 1885: 65). Within the north-west wetlands at least, our trackway evidence for the Iron Age is still slight; perhaps these bogs saw less activity than their Irish, German or Danish counterparts, epitomising the resource-poor 'wet desert' envisaged by Hall et al. (1995: 199). Yet the building of these tracks brought communities together, just as turf cutting would have done. A project like Corlea may have taken a local 'king' to command its construction, but this was on a huge scale. To get at the character of cooperative work for many of the other tracks, we can look to Henry Glassie's (1995) ethnography of peat cutting at Ballymenone. Like track building, the demands of cutting and carting turf made it an arena in which help was exchanged ('swappin', as his interviewees put it): families and neighbours got together in what was a sociable time, where meals 
were taken in the bog and gossip and storytelling was had. Work in the bog had its own time and rhythm: it was hard but it had 'great value' (Glassie 1995: 485), especially where there was illness or misfortune in the house. Then, neighbours would pull together in groups ('methals') to get the work done - knowing 'if things go awry, you will not have to meet them alone' (Glassie 1995: 484-5). Even the rescuing of a cow from the bog became a moment of liveliness and humour: 'and often, maybe the rope broke, and maybe four or five men would fall on top of other. It was a bit of sport, do ye know' (Glassie 1995: 484). The rope may have broken but neighbourhood bonds were pulled tighter.

\section{The fatal burden: death and disaster in the bog}

When people with a good knowledge of the bog were around it was a less fearful place, but any crossing, on a trackway or not, had to navigate the bog's surface, an experience that could be both unsettling and dangerous. As King (1685: 952) noted: 'I have gone on Bogs that would rise before and behind, and sink where I stood to a considerable depth; under was clear water, as some of us experienced by falling in with one leg up to the middle ... breaking the surface of the earth where we stood'. The Earl of Cromertie was even less fortunate: visiting the bog at Lochbrun in 1651, he was warned 'none could pass over it, for the scurf of the bog would not support them', yet 'I would needs try it; and accordingly fell in to the armpits but was immediately pulled out by them' (cited in Christison 1881: 166). Local knowledge was invaluable. Navigating the channels between hummocks in Connemara's Roundstone bog, Robinson (2007: 16) comments on the streams that seemed 'impossible to jump unless you know the right spot to aim for'. As a result, great bog walkers from Roundstone, who knew the land and could travel it at speed, were famed for their almost supernatural navigation (Robinson 2007: 18). The peat expert, Harry Godwin, recalled touring the Bog of Allen during 1935. With his botanist's eye, he quickly learned how to discern the difference between supportive tussocks of ling, heather, cotton and deer grass, to avoid the shallow bands of drainage channels or bog 'soaks': here, the open mat of floating Sphagna would indeed, as he put it, propel the 'jay-walking botanist' into deep water! Poor weather such as fog could easily disorientate. In Lewis, people relied upon the 'innis' and 'aster' of the cattle, or in the north of Britain, the 'heafing' of sheep, following the 'natural instinct of an animal to return to the area of the bog where they spent their first summer' and the route back home to the farms (Crawford 2018: 60). Human navigation was more precarious: a couple trying to collect a marriage certificate in Belgium in 1871 died in a snowstorm in the Hautes Fagnes, having become disorientated; their passing was marked in the bog by a 'lovers' cross' (van der Sanden 1996: 23). For moors and marshes were, as the early traveller Daniel Defoe noted ([1738] 1971: 516, letter 9), 'difficult, and sometimes dangerous, especially for strangers'. 'Accidents, as is natural to suppose, are not unfrequent among cows and sheep, which, ranging for food, sometimes slip into 
the Moss Pits and Trenches' (cited in Worthington Barlow 1853: vol. 1: 45). These are the words of Samuel Finney, writing about Lindow Common in 1785, but they apply to any of these bogs (e.g. Glassie 1995: 484).

The loss of stock is a common theme. On her 1698 tour Through England on a Side Saddle, Celia Fiennes (1888: 171) made a point of avoiding Martinmere in Cheshire, for 'as ye proverb says, [it] has parted many a man from his mare'. King (1685: 952) too lamented this danger: 'They keep People at a distance from one another ... a great hindrance in passing from place to place ... a great destruction to Cattle ... the edges of the Bog have commonly grass; and the Cattle, venturing in to get it, fall into pits and soughs; \& are either drownd [sic] or ... spoilt in the pulling out'. The danger to herds and flocks was exacerbated in the eighteenth and nineteenth centuries by their close cropping on nearby improved pasture and deeper drains at its edges (indeed, dedicated 'Pinners for the Mosse' were employed in Ashton to retrieve straying cattle, see Bowman 1960: 46), but it was not just stock that were lost. In the Outer Hebrides, on Lewis, a gravestone poignantly recalls the death of 'Ealasaid (Elizabeth), 6, drowned on the moor' (Crawford 2018: 42), while in 1867 four-year-old Alasdair MacDonald tried to follow his mother who had gone out cutting peat with her creel on her back, but he too became lost and was also drowned (Crawford 2018: 62). On Roundstone bog in Ireland, an elderly man returning from the local workhouse was caught in a 'terrible storm ... went astray and died' (Robinson 2007: 19). By the time he was discovered 'in a little hollow' it was too late. Robinson (2007: 19) recalls the account that the old man 'had wrapped himself in heather to keep warm' but his body 'was very decayed; they had to bury him at the spot' - a bog body in the making. Finney's account of Lindow Common mentions a now notorious pair of deaths that bring to mind the supposed fate of 'Red Christian' in Denmark: 'Men also have found their last home upon this dreary place too, in my memory. Nat Bell, and Radcliffe, returning home, loaded with ale, fell under the fatal burden, and died before the morning' (cited in Worthington Barlow 1853: vol. 1: 45). One of the interpretations of the medieval body from Tumbeagh - found mere metres from a bog trackway - is that she strayed accidentally from the path at a time when the bog's surface wetness had become particularly treacherous and was quickly subsumed in a bog pool, being unable to regain firm footing (Bermingham and Delaney 2004). Coles and Coles (1989: 178) also recall the discovery of a body from Vehne bog (north Germany) who was found with 'tufts of heather in his hands, and lay on his front with arms outstretched', suggestive of someone trying to claw their way out of the morass. Historic examples of fatalities associated with the bog are known from Germany, the Netherlands and Denmark (van der Sanden 1996). In a more recent survey of Scottish bog bodies, Cowie et al. (2011) attribute a number of the historic remains to accidents on the bog, perhaps during bad weather (such as Gunnister and Clayton Hill) or foul play (Quintfall and Arnish) examples that will be further discussed in Chapter 6 .

Prolonged wet weather brought yet another risk: that of the bog burst. This occurs when the Sphagnum moss becomes saturated beyond carrying capacity and 
its delicate 'acrotelm' (described by van der Sanden (1996: 23) as like the 'skin' on porridge) is punctured. This phenomenon can happen with either a blanket mire or a raised bog (Fischer 2012: 65). Though normally weather-driven, anthropogenic activity exacerbated this risk - altering patterns of natural drainage and splitting this fragile surface. Occasionally this has been recorded in the field: Godwin describes the burst at Glencullin, Co. Mayo, in 1935, where excessive rain resulted in a rupturing 'porridge' of peat that covered the lower part of the valley to a depth of $5 \mathrm{~m}$, draining a bog lake and leaving behind huge crescentic crevasses of rotated blocks of upper peat (Godwin [1981] 2009: fig. 22 and pl. 22). Other events are well attested in the historic literature (Feehan and O'Donovan 1996). One of the most famous accounts relates to Chat Moss in Lancashire, recorded by Leland in volume $\mathrm{V}$ of his Itinerary in England and Wales in 1533, only seven years after the event:

Chateley More a vj miles in length sum [way] brast up within a mile of Morley Haul, and [de]stroied much grounde with mosse therabout and destroid much fresch water fische therabout, first corrupting with stinking water Glasbroke, and so Glasebrook carr[ied] stinking water and mosses into Mersey Water, and Mersey corrupted carried the roulling moss part to the shores of Wales, part to the Isle of Man, and sum into Ireland. In the very toppe of Chate moo[se] there the mosse was hyest and brake, is now a faire plaine valley, as was in tymes paste, and a rille runnith in hit, and peaces of smaul trees be found in the bottom. (Cited in Toulmin Smith 1964: 42-3)

The damage wrought in this event is clear - even if its supposed geographic reach might raise an eyebrow. Crofton published a more visceral account of this event in the papers of the Gray family, Earls of Stafford, transcribed from a single sheaf of closely written ink, on paper that bears the watermark of a hand and a star, dated 29 January 1526. The document (possibly copied from a contemporary broadsheet) is entitled 'How Chatmos brake out \&c' and its tone and spelling conjure the fear associated with such a phenomenon:

As yt is thought by grett abndance of Watr \& mude co'gelet [congealed] to geythur wyhtin the said mosse apon ye west end brake owtt ... and there came so grett abndance off mosse downe, by reason off the sayd watr \& muddyd, yt fylled a reu [river] called Glasebrock ... In grett jopde [jeopardy] \& stand in the watr some to ye easing [eaves] and abowe yt, in so meche ye in habitors had myche payne and sorowe to save theyr \& theyr children vndrowned, \& yet, thanket be to god, no cystyn body was pisshed, butt yt they lost ther godes in ther howss, wt ther corne \& hey in theyr barnes, \& some swynne \& dogs drowyd ... they sey yt by yeyre trwyth, all they thought yt had bene domesday, by cause ye watr \& mosse wt growing trees yron dyd mete wt so grett vyloenc \& came tomlyng to ward yey, \& they dyd cry apon theyre neghbors to saue yeyre selffs. (John Rylands CLD/133, in Crofton 1902: 142-4)

No wonder they thought it was Domesday - the bog destroyed housing, property, livestock and stores and polluted the watercourses downstream: they were 'so corruppyd that nether beasts more Cattellez wyche [will] dryncke ye off [thereof]' 
(Crofton 1902: 144). Famous bog bursts are recorded at Solway Moss in 1771 (Walker 1772), Pilling Moss in 1744 (van der Sanden 1996: 23) and Hough Moss (Higson 1859). Upland blanket bogs could also behave in this way: Patrick Brontë (1824) (father to the literary family) gave a sermon on the apparent earthquake and 'extraordinary eruption of mud and water' from Crow Hill in 1824. He saw it as a divine portent to repent, reporting that it sounded like thunder and shook the house, forcing his children to shelter in a nearby farm porch. A storm seems to have precipitated this event but winter was always a risky time: Higson (1859: 158) describes the Ashton Moss as becoming 'swollen out with rains' that overflowed the fields 'at the back end of the year'. Some of these bursts were fatal: in 1897, Praeger (1897: 143) was sent by the Irish Royal Society to describe the effects of the Knocknageeha (Killarney) bog burst of 27 December 1896. This time the 'roaring flood of black fluid' completely destroyed the first cottage it met and the whole Donelly family - husband, wife, six children and stock - perished. One of their bedsteads was later found fourteen miles away (Praeger 1897: 142) and witnesses recalled the subsequent pulses of peat water as sounding like 'big guns or the rumbling of thunder' (Praeger 1897: 144). Praeger (1897) reports on eighteen other bog bursts known to him from Ireland (further discussed by Feehan and O'Donovan 1996), including Woodfield bog burst (illustrated in van der Sanden 1996: fig. 18), several with fatal consequences. He was particularly affected by seeing first-hand the effect of the Knocknageeha burst, which included not just the 'porridge' of peat but the ancient basal tree vegetation: 'The appearance of this extensive sea of black peat, with its protruding stumps of blackened trees, overlying fertile fields, was a sight melancholy in the extreme ... Many farmers have suffered serious loss by the tearing up of their potato pits ... The tenants being all smallholders, the loss of their best grazing has ruined them' (Praeger 1897: 149-51). Portents of the burst were reported as sounding like a 'banshee'; the local parish priest had apparently been summoned to pray with several families, prior to the burst (Praeger 1897: 152).

Supernatural intervention was also suspected back in northern England, on the White Moss of Theylemoor. Earl Cowper (of Melborne Hall, Derbyshire) began his account of this burst by saying: 'We have forewarning signs of God's judgement $\ldots$ by the violence of the wind and the water it [the moss] removed itself ... and it went violently ... it so putrified the water that our water [at Manchester] was as black as a moss pit, and at the Hunt's Bank it left I think near a hundred load of moss earth' (cited in Crofton 1902: 141). The same event was also mentioned by Hollinworth in his Mancuniensis, who reported that on New Year's Day in 1633, 'the [white] moss ... rose up out of his place and travelled towards the house of James Knowles and environed it about, carried a large stone trough before it and boar down trees that stood in its way' (cited in Crofton 1902: 141). Hollinworth goes on: 'It filled the brookes and rivers, slew the fish, blackened the waters, [and] made some fruitful land barren' (cited in Crofton 1902: 141). Many of these bursts went unrecorded: a note on Lindow Common dating to 1847 by a witness named Comberbirch (1847) stated that the bog had been 'laid dry about fifty years ago 
soon after the time of the great flood' and given the time frame, this probably refers to a localised bog burst rather than the apocryphal biblical event. We know that these bursts were also occurring in prehistory, recorded, for example, on Bourtangemoor in the Netherlands c.500 BC (Casparie 1986: 180), possibly related to bog ore extraction, and on Derryville bog (Ireland), where a section of trackway known as Killoran 18 was heavily disrupted by redeposited peat from such an event (Gearey and Caseldine 2006, fig. 4). Using testate amoeba to investigate bog surface wetness integrated with prior work (Casparie 2001), Caseldine and Gearey (2006) posit five bog burst events at Derryville, of which three more fall in our period of interest: 88 BC, 600 BC and AD 200-250. Indeed, the event of $c .600 \mathrm{BC}$ is attributed to the injudicious placement of a major large roundwood trackway (known as 'Cooleeny 31') across the main discharge channel in the south of the bog - 'ponding back' a large volume that then drained catastrophically out of the bog (Casparie 2001: Caseldine and Gearey 2006: 599).

Bog bursts were often a mix of local weather, environment and human factors. They would have been part of later prehistoric communities' lives but lower population densities and radically different attitudes to land probably meant that fewer households encroached so closely upon its fringes, resulting in less damage to settlement and stock. What the historic accounts do give us, however, is an insight into how this behaviour may have shaped understandings of the moss itself. The bog 'brast up' for Leland or 'removed itself' for Cowper; it was a 'roulling moss' according to the anonymous transcript from 1526, translated by Crofton (1902: 140) and a 'wandering mosse' in Leland's account (Toulmin Smith 1964: 3). This motif of the 'travelling bog', as Higson later put it (1859: 159), gave the bogs a sense of animacy and destructive agency, which would have been palpable in the ancient as well as recent past.

Complementing this quality was the still and deep power of a bog pool or 'pit', often a natural feature caused by a deeper basin within the bog (as was posited by Buckland (1995) for Lindow Man), but sometimes the result of ancient diggings for peat. The Drumkeerah bog body, whose textiles so fascinated the Countess of Moira (1783), was deposited in a 'small turbary' or 'cauldron bog', and Yde Girl was similarly placed in a bog pool formed in a fossil pingo (Chapman 2015). Both Tollund Man and Grauballe Man are now thought to have been placed in old 'peat cuttings. The intense lens-like power of such a feature should not surprise us: a fabled 'mighty deep hole' within the 'black bog' at Gipwell on Thornholme Moor was reputedly the place where local robbers hid their black deeds: 'If they put their victims in,' commented de la Pryme (1870: 65), 'I have no doubt they would soon sink into this bog and never be heard of again'. Similar tales of unwary travellers seeking shelter for the night and being murdered for their meagre possessions then dumped in bog pools or lakes were recorded by Robinson (2007: 45) from Roundstone bog. In Moston ('moss town', Manchester), Roeder (1907: 70) recalled that 'one of the pits harboured an uncanny evil spirit ... and was called the Devil's pit'. Stovin (1745, cited in Buckland 1995: 50) notes that such features were 'always full to the Top ... the water Black'. Hatfield (1866, cited in Buckland 1995: 50) 
goes on to say that the Thorne Moor pits were thought by the 'superstitious' to be bottomless, but that they were certainly the most deceptive and treacherous features on the moor due to the way Sphagnum grew over the margins, sometimes covering the pool entirely.

These deep pools also attracted another kind of victim. In October 1655, Mary Daniell, 'servant to Anne Heywood', is recorded in the parish registers of Ashtonunder-Lyne as having 'drowned her selfe in a pitt upon Dukinfield Moore the 9th day att evening, when she had milked' (Brierley 1927: 396). Her care for her cattle, before her own demise, seems especially poignant. Whether 'William, son of Gervais Walker' did indeed drown 'by accident' in another such pit on 14 April 1664 (Brierley 1927: 410) is unknown; suicide in this region carried its stigma of exile from consecrated ground, as the crossroad burials discussed in Chapter 2 reveal. Cowie et al. (2011) also add at least one known suicide buried near Berrybrush in Scotland to this picture, while the Tumbeagh bog body mentioned above might just as easily have walked 'off the track', surrendering herself to the bog (or been buried there by concerned relatives), rather than slipping in by accident (see discussion in Bermingham and Delaney 2004). In landscapes devoid of seashores, lakes or large rivers, the bog lured those in despair. This was not unique to Britain: Kama (2016) records twenty-eight 'place-lore' records of drownings in bogs in Estonia, of which ten were known suicides, all women. One common motif is of voluntary self-sacrifice by a group of women who drowned themselves rather than risk rape or murder during wartime (Kama 2016: 7), whereas a folkloric bog body character named 'Triinu' is variously described as a single pregnant woman, a hard-working servant captured by the devil, a witch, haughty woman or serf/ slave deliberately killed by her masters (interestingly, conveyed in 'wheelbarrow' or cart, from which birches grew to mark the spot, see Kama 2016: 8). Other tales of femicide (murder by a spouse or known male) were narrated by recent inhabitants to interpret discoveries of 'bog bodies' from the Estonian peat (Kama 2016: 12).

We do know that in Britain these deeper pools and pits on the moss gathered a malign reputation. The Tudor Wyatt Moss map, for example (Figure 4.2), shows a patch of small, black dots to the west of the moss, referred to in associated documents as the 'hell holes': the one enduring and mappable feature used to locate turbary rights across a century of disputes (Shannon 2015: 67). The name is similar to the 'Hell's Kettles' recorded by William Harrison (a Tudor chronicler) near Darlington, in which it was thought souls would be 'seethed for their sins': a literal place of purgatory (cited in Watkins 2013: 70). As on Hatfield, the locals thought them to be bottomless, but their depths were plumbed by one Jabez Kay in the 1690s, apparently in 'a bid to banish the belief' (cited in Watkins 2013: 70). The term seems to stem from early Christian readings of hell on to a novel 'pagan' landscape (Semple 2003). Citing the eleventh-century need to physically substantiate what damnation might look like, Semple (2003) notes that the Harley 603 Psalter (an English copy of the Utrecht Psalter) is pock-marked with dark circles meant to represent hell 'mouths' or 'pits'. Semple (2003) convincingly relates this to tumuli (prehistoric burial mounds), noting the link between one image and 
Psalm CXLIII.3, which states that 'he hath made me to dwell in darkness as those that have been dead of old', but encounters with human remains from the bog would also fit the psalm's motif. Certainly, the notion that hell was a hole that might literally open under one's feet (Semple 2003: 236) clearly had resonance with locals living near the moss, or those who tried to cross the bog. That they might be portals to hell was believable; indeed, as Chapter 2 has shown, such locales were used to handle the 'dangerous dead'. Alongside Abbot Brihtwold and the revenant priest John Tankerley, the Vita of St Kenelm records that Princess Cwoenthryth 'could not be kept' in the church nor the cemetery nor the field, and was finally 'thrown into some remote, deep place', while a sherrif who had violated St Edmund's sanctuary and apparently also 'walked after death', was exhumed from his grave, sewn up in calf skin and immersed in a pool - both descriptions interpreted by Blair (2009) to mean mosses or bogs.

It is understandable that the reputation of the moss and the bog as an 'otherworldly' place gathered force in the post-medieval period, once enclosure tightened the formal boundaries of the parish and demarcated the improved and cultivated land from the 'waste' of the moss. Whinney Moor, for example, in North Yorkshire, was seen as the physical embodiment of the journey the soul had to undertake - a walking purgatory - as recorded by the antiquarian John Aubrey in a seventeenth-century funeral dirge (Watkins 2013: 69). Formally 'waked' by its family, the deceased had to leave the comfort of 'fire and fleet and candlelight' to cross the tussocky moss, eased or troubled by the person's good works, to enter heaven or hell as their fate dictated. Watkins (2013: 69) describes this as 'a medieval world in miniature, lived out through the local moorscape.

Through these historic sources we gain a glimpse of the character of the bog, its animacy and its potential to take life. Bog pools and hummocks shaped different kinds of interaction, possibilities and fates. We appreciate better the risks people took in crossing the moss to win turf or ore, and how they tried to navigate its dangers through formal trackways, yet also how its features and apparent behaviour gave rise to associations with the supernatural. It could be a place where the living passed into death, both accidental and deliberate; where worlds might touch and where encounters might be had with beings that moved between those realms. These latter qualities owed much to strange phenomenon produced by the decaying environment of the peat itself.

\section{Wandering fires, boggarts and the walking dead}

In book IX of Paradise Lost, the British poet Milton ([1667] 2014: 274) writes of the 'the wandering fire / Compact of unctuous vapour, which the night / Condenses, and the cold environs round, / Kindled through agitation to a flame, / Which oft, they say, some evil spirit attends, / Hovering and blazing with delusive light / Misleads the amazed night-wanderer from this way / To bogs and mires, and oft through pond or pool; / There swallowed up and lost, from succor far'. 
The phenomenon that he evoked was the 'ignis fatuus': witnessed across northern Europe as a dancing, flickering flame above bogs, featured in British and Irish folklore as a malign spirit, tempting travellers to their doom. Once thought to be the result of self-igniting bog or marsh gases (Crum 1988; Mills 2000), they have most recently been discussed as a possible example of an extremophile: a biochemical reaction indicative of a biogeologically stressed environment (Edwards 2014). Few modern sightings of this phenomenon exist, supporting the notion that the very environments that once produced it have been irrevocably altered (Edwards 2014). Nonetheless, they were once often observed as a bluish flame with yellow centre, wavering up to $2 \mathrm{~m}$ above the marsh or bog surface. Where they were physically interacted with, they were found to be affected by moving air currents (hence their 'dancing' appearance when approached), cool to the touch and apparently readily extinguished (Edwards 2014: 3). In British folklore from the 1300s onwards, they were variously known as 'will-o'-the-wisps', 'ghosts' or 'corpse candles', linking them with death and an other-worldly presence. One of these was reported by Abraham de la Pryme (1870: 63), as told to him by a father and son who had encountered the lights above Hatfield moss together in the late 1600s/early 1700s: '[It] went dancing and leaping before him ... when he went, it went, and when he stood still, it stood still; he lights and tys his hors [sic] to the hedge, and falls at it manfully, making the piece fly one way and another ... attesting seriously and robustly that he had kill'd the divel'. Another report in de la Pryme's diary recounts that 'a gentleman in the country say that he once got an ignis fatuus, and affirm'd that it was nothing but a shineing [sic] froth' (de la Pryme 1870: 64). Yet the notion that they were wayward forces was used by Methodist preacher Nash's sermon: a tirade against a fellow cleric, entitled The Ignis Fatuus or Will-o'-the-Wisp at Providence Chapel, Detected and Exposed (1798). He used the analogy of this phenomenon to describe the lure of this excommunicated priest over his 'admirers' who were led astray into the 'bog' of his beliefs! This metaphor would have been readily understood by the inhabitants of Ashton and Droylsden Moss, where Higson (1859: 67) notes a particular association of the lights with autumn, when the lambent flickering flame (carburetted hydrogen, spontaneously ignited) of the "Corpse Candle", "Will-o'-the-Wisp" or "Jack" or "Peg-alantern"... performed his or her fantastic and impossible jumps, in the plashymeadows near Edge-Lane, to the terror of many'. In The Owl Service author Alan Garner (1967) conjures a haunting encounter with this 'marsh gas', at the edge of a wooded moss, as a precursor to the unfolding of an eternal love triangle. These lights continue to be reported into the twentieth century, but perhaps more as folkloric remembrances: on Chorlton bog they have been attributed to 'one of the several people who drowned on these marshes, possibly a suicide' (Hough and Randles 1993: 30). The notion that the bog was a place where the dead might be seen is echoed in Robinson's story from Roundstone. At the end house on the Bog Road below Ardagh, a girl of seven years old swore she saw her father 'a long way off in the bog, carrying a sack or a net of fish' after a day out on the boat (Robinson 2007: 17). Soon after, his body was washed up on the shore, drowned. 
In addition to these lights and apparitions, each wetland has its supernatural 'bog' folk. In her study of the 'hazards of the bog (real and imagined)', Meredith (2002) lists Seamus Heaney's 'mankeepers' and 'mosscheapers': 'creatures uncatalogued by any naturalist but none the less real for that' (Heaney 2002: 4). The very words, Heaney (2002: 4) wrote, contained an onomatopoeic resonance: 'the soft, malicious sound' of 'collapsing sibilants coaxing you out towards bog pools lidded with innocent grass, quicksands and quagmires. The water sheeries and bog sprights also haunted its pools, while in Denmark, bog witches, kings and elves are preserved in Hans Christian Andersen's tales (Meredith 2002). These figures ooze malevolence, taking their due by pulling naive or selfish humans into the bog, like the proud Inger who used her mother's bread as a stepping stone to avoid getting her shoes dirty (Meredith 2002). Wright (1913) lists the Lancashire character of 'Jenny Greenteeth' and the Yorkshire 'Grindylow' as a kind of water demon who inhabited deep, stagnant pools to drag children to their doom. Such entertaining tales were garnished with a landscape moral: warning adventurous youngsters of how she 'lurked at the bottom of pits, and with long sinewy arms dragged in and drowned children venturing too near' (Higson 1859: 67).

Yet there was a very particular form of northern British bog dweller that turns up repeatedly in its folklore. The ignis fatuus of Ashton Moss appeared close to a property named on the 1848 six-inch Ordnance Survey map as 'Boggart House' (Figure 4.4). Writing around the 1820s-1830s, Joseph Lawson recalled his parent's firm belief in three forms of supernatural entities: 'ghosts, boggarts and spirits' (Watkins 2013: 191). The etymology of the 'boggart' was mired in the world of the moss but by the time it was being recorded in folklore (e.g. Roby 1829; Keightley 1850; Henderson 1879), the boggart had become somewhat domesticised, with

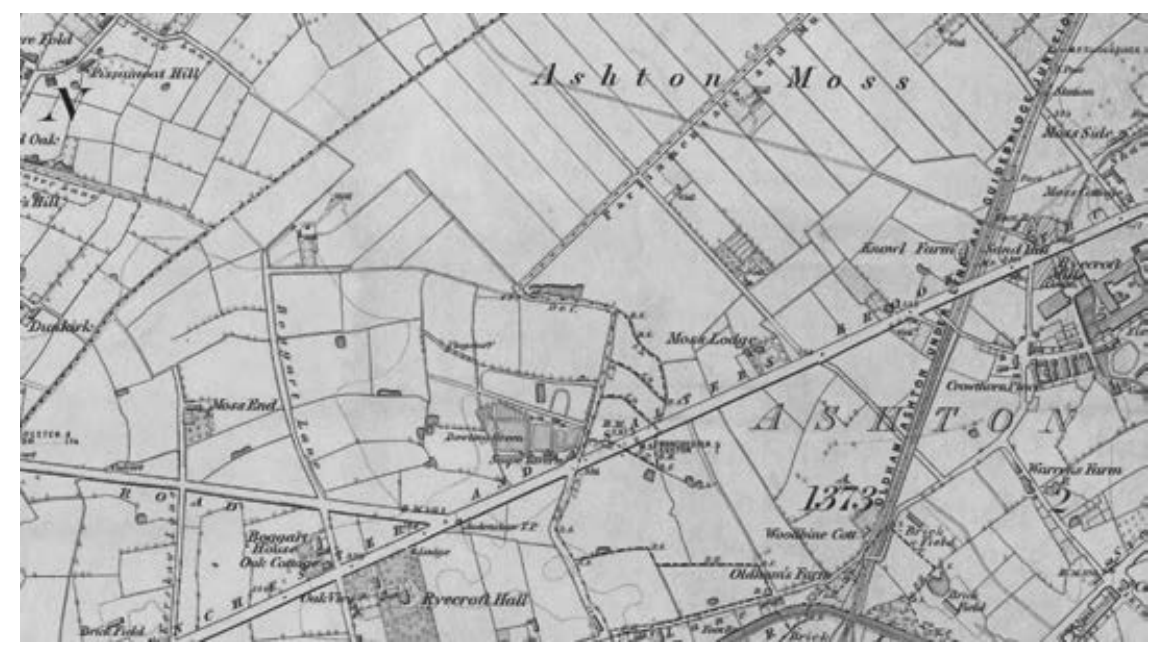

4.4 'Boggart House' on the edge of Ashton Moss, showing Little Moss to the north - the 'far-end-of-th'-world'. 
motifs borrowed from Irish and Scottish folktales to explain local place names such as 'Boggart Hole Clough' (Houlbrook 2011). In such stories, this local supernatural entity was reduced to an impish resident of farms, who liked pushing over children and spilling their milk, like the 'Clayton Hall boggart' from Ashtonunder-Lyne: a noisy poltergeist, notorious for causing domestic misery (Higson 1859: 69). The apocryphal tale of the family forced to 'flit' their farm ends with the boggart himself calling out from the milk churn in the back of the wagon that he too is 'flitting'; the family reluctantly return to their house, resigned to his mischief (Briggs 1979: 28). Higson (1859: 67) mentions such a boggart alongside a pantheon of bog denisens: 'Many domiciles, also, had their presiding boggart, and feerin' swarmed at every turn of the dark old lanes, and arch boggarts held revel at every three-road end'.

This account introduces us to the more local form of 'country' boggart, altogether more malign (Young 2013). Four-footed boggarts (taking the form of 'great big dogs') would apparently 'issue from a pit at [the] East End' of Ashton Moss (Young 2013). These presences were a reality to bog inhabitants: in 1785, Finney wrights scathingly of the Lindow Commoners who were 'so exceeding credulous and superstitious that ... Fearings and Boggarts lurk in every dark hole and gloomy hollow-way' (cited in Worthington Barlow, 1853 vol. 11: 122). Interestingly, Roeder (1907) described this as a 'peopling of brooks, pits, lanes and cloughs' with spirits. It is easy to romanticise this superstitious belief. The Victorians were radically transforming this land and in so doing altered the very 'landscape they carried round in their heads' (Watkins 2013: 130), turning these phenomena into the stuff of entertainment, instead of the fabric of life. These stories of boggarts told people how to live well but respectfully with the moss (see Basso 1996); it was a dangerous place, and so among them the stories and the fears endured. Such a land required specialists who could deal with this supernatural realm. One, Jem Hill, styled as 'th'king of Dregihlsden' [Droylsden] claimed the nearby Green Lane 'swaarmt wi'fairies, witches un boggarts, which nob'dy could mester bur hissel', while a certain 'J. W. is cited as the last of 'an ancient race of boggart seers ... [who] used to combat with feeorin' (cited in Higson 1859: 68, 69). Other measures might need to be taken: Eyre (1974: 34) reports that the large sandstone block that gave 'Written Stone Lane' its name in Longridge was supposedly used to entrap a boggart, carved with the perpetual warning that 'RAVFFE RACLIFFE LAID THIS STONE TO LYE FOR EVER AD 1655'. Whether or not this was its original purpose, attempts to remove or reuse it have not ended well, so it lies there still.

Finally, among the other-worldly presences on the Lancashire bogs, Higson (1859: 68) also mentions 'the terrific exploits of headless trunks or men 'bout heads' - such tales may well have been fuelled by the discovery of bog body parts, such as the prehistoric Ashton crania. The Ashton Weekly Reporter (Anon. 1860: 2), for example, reports on the superstitious cottagers of 'Back Openshaw' who 'were much disturbed by boggarts [and] feorin', and told that the red staining on floorboards in one of their dwellings came from a murder long past. In 1733, 
the levelling of the Ashton road disturbed the remains of 'some mouldering bones and a human skull' in a copse or hedge bank, which was attributed to this violent incident (Anon. 1860: 2). The remains were handed over to the local sexton who gave them a shallow grave in Gorton Chapel, but their discoverer (a 'notorious toper' $[s i c]$ ) could not resist periodic exhumation of the skull to take it to the George and Dragon pub nearby, apparently to 'drink ale from it if anyone would pay the shot'! (Anon. 1860: 2) It is a step too far to link this to an actual bog body, but it warns us that attitudes towards human remains - whatever date was ascribed to them - were a little peculiar in Lancashire.

Such mosses and marshes harboured other strange phenomena. On Thorne Moor in the early 1700s, Abraham de la Pryme (1870: 11) reported 'a great circumnavigation of whirling which made a noise somewhat like the motion of a milstone [sic]', heralding the appearance of a water spout: 'ever and anon it danced down out of itself a long spout'. Meanwhile, Camden attributed a bog burst to lightning strikes (cited in Feehan and O’Donovan 1996: 409). Micro-meteorological and physical effects of the bog still mystify - Meredith cites a field visit to a quaking bog in Vermont by a pair of naturalists, during which:

We heard the sound of something slicing quickly through the shrubbery. As the sound intensified, we noticed a small black spruce tree being whipped back and forth by a forceful, swirling wind ... After making a few passes ... it simply vanished. Where did it come from, and how did it happen on such a calm day? (Rezednes and Roy 1996, cited in Meredith 2002: 319)

In the end, the naturalists attribute this mysterious movement to the isostatic dynamics of the quaking bog itself: their very footfall has created a rippling dynamic through the liquidity of the peat, which disturbed the distant vegetation. Yet even for these scientists, as Meredith (2002: 319) notes, this sense of an animate, invisible presence was altogether real and unsettling.

At the end of his account of folk tales about Roundstone bog in Ireland, Robinson (2007: 45) urges caution: 'It may be all a dark absurdity, words put together to conjure up all the shudderings and black treachery of the bog and condense them into a tale. Yet the historical sources drawn upon here suggest otherwise: physical dangers, bog behaviour and luminescent phenomena further enhanced the 'other-worldly' reputation of the bog as a place where past and present met or where one might cross between this world and the next. As the bog grew in later prehistory, its perceived animacy must have swelled too, and for the rational, scientific mind of the eighteenth and nineteenth centuries, this was a folkloric horror to be physically and culturally drained.

\section{'Frightful to think of': pejorative associations of the bog}

In his survey of Lancashire, Defoe ([1738] 1971: iii: 170, letter 10) described 'Chatmos' as looking 'black and dirty, and is indeed frightful to think of, for it 
will bear neither horse nor man'. As land, it was to his eyes 'waste', its water the colour of 'stale beer' (Defoe ([1738] 1971: iii: 171). In the Lancashire chapter of Britannia, Camden (1722: 962) also commented on these 'moist and unwholsome places, call'd Mosses' of Lancashire, referring also to the Fens as 'filthy bogs ... and unpassable marshes' to which Gibson added a personal note that 'these are now much altered by draining' (Camden 1722: 962). In Ireland, William King's essay 'Of the Bogs, and Loughs of Ireland' (1685: 948) set out to 'consider the Origine; their conveniencys, and inconveniencys; how they may be remedyed, or made usefull'. King (1685: 948-9) believed 'the real cause of them is wont of Industry', going on to note, 'no wonder that a Country famous for laziness, as Ireland is, abound with them'! He worried that they were a shelter to 'Torys and Thieves', and mentions the 'smell and vapours' from bogs as 'putrid and stinking' (King 1685: 953), setting out a series of ideas for their compulsory drainage and drying out. After viewing the damage of the Knocknageeha bog burst, Praeger (1897: 162) dolefully wrote that 'a few organised attempts have been made from time-to-time to turn some of our bogs to better use, but the want of success ... seems to have discouraged further effort ... a possible source of vast national wealth has been left to undeserved neglect'. In Scotland, Steele's The Natural and Agricultural History of Peat-Moss or TurfBog (1826) drew on his own experience of transforming Cobbinshaw bog. It was 'considered as worth nothing' upon purchase, but Steele (1826: 394) reported how he had turned it into an 'excellent pasture ... diversified with thriving plantations', finding in the process a hoard of Roman silver 'medals' - one coin aptly stamped with an image of Ceres bearing stalks of corn (Crawford 2018: 155). This vision of the bog as an unproductive morass, rather than an integral part of the natural environment and hydrological system, was shaped initially by the classical authors, whose texts formed the basis of elite education. The paladimus fieda of Tacitus (the 'foul bog') was the site of ritual sacrifice, offerings to the goods as well as a means of execution for various crimes (Aldhouse-Green 2002). Vitruvius's treatise On Architecture warned against living anywhere near a marsh, since 'the vapours of the fens ... the poisoned breath of marsh animals' made the site 'pestilential', while Columella's De Re Rustica complained of the 'baleful stench' of marshland and the 'plagues of swimming and crawling things ... infected with poison by the mud and decaying filth, from which are often contracted mysterious diseases' (cited in Aldhouse-Green 2016: 51). This pejorative vision was shaped by the Roman invader of an alien landscape, and as these texts were read and absorbed by the eighteenthand nineteenth-century upper- and middle-class improvers they found sympathy with its views. They mined these texts to support the radical changes they believed necessary to improve both land and people. From her side saddle, Celia Fiennes (1888: 171) opined: 'If Gentlemen would set about it, Most of ye Waste Ground that is now a ffenny Moor and Mostly water might be rendered usefull'. Finney's 1785 notes on Lindow Common recall it as a 'wild moss, which was very extensive before the Turves were got out' (cited in Worthington Barlow 1853: 42), but, he went on: 'In its present wild uncultivated state it only yields a scanty nourishment to a few small cows, scabbed tits, lean sheep, and geese. But I am of opinion 
that even the wild Moss itself might at a small charge be drained and converted into meadow and rich grass land' (cited in Worthington Barlow 1853: 43). These arguments were being played out across northern Europe, particularly by the Dutch for whom large-scale drainage and land reclamation was pioneered as a matter of necessity. However, in the British Isles, they were also used to secure the final seizure of marginal lands that had survived in common use, placing it instead under the control of the landed classes: allotting land only to those who could afford to pay for it. In England, such improvement went hand in hand with the enclosure movement (Hoskins [1955] 2013), and in Highland Scotland and Ireland with the notorious clearances that saw landowners shift from clan-based, croft tenantry (managed on the ground by the 'tacksmen') to large-scale sheep pasture systems (Devine 2018). A photograph of a 'labourer's hut' at Gweedore, Co. Donegal dated to 1880 , shows a family of four standing outside a hut made of turf cut from the bog, with longer strips used to cover the roof and one small glass-paned window inserted into the wall: a temporary home 'following eviction' (National Library of Ireland n.d.: Lawrence collection no. 1, 508). In Scotland, on the estate of Blairdrummond, the philanthropically minded Henry Home, Lord Kames, sought to both ease the plight of the dispossessed Highlanders and improve the Blairdrummond Moss by offering each family thirty-eight acres of moss, rent free for eighteen years (Crawford 2018: 145). They too built their homes out of the turf, cutting and draining it around themselves, until they had reduced the morass of peat to the basal alluvial clay, from which these Gaelic-speaking 'moss lairds' (as the locals jeeringly called them) made a productive farmland (Crawford 2018: 146).

The bogs matched a contemporary sociopolitical geography that favoured the south, and they were used as a metonym for the north and its peoples, perceived as culturally backward and politically marginalised. It was all too easy to translate the perceived properties of these places on to the people associated with them, most notoriously in Ireland, where 'colonial stereotypes of the Irish as bog men or bogtrotters abound in eighteenth and nineteenth century texts' (Kavanagh 2019: 68). The moss was a metaphor for laziness, intractability and superstitious belief, creating a Celtic, Catholic caricature that was the butt of both loathing in literary works (such as the 'noisome bog' in Swift's A Tale of a Tub) and political satire (where the word 'bog' was often used in a knowing double entendre, as in popular prints by Hogarth, see Pittock 1999: 32). Bram Stoker's 1890 story The Snake's Pass personifies the evil character of the bog as a consuming and cruel entity, embodied in the treacherous snake as a merciless harbinger of death. These tropes spawned twentieth-century literature that widened the associations of the bog with the ungoverned psyche (as Freud saw it, see Chapter 2) - lack of physical control, uncouth and uncultured habits; sterility, weakness and femininity (Sanders 2009, Kavanagh 2019); or political treachery and nationalism (Pittock 1999). As Heaney (1999: 3) points out, the bogs were also a way of underpinning 'urbs against the rus, the stand-off between the urbane citizen and the rusticus'. Thus, Aldhouse-Green sees the bog as a suitably liminal place for Iron Age and 
Roman sacrifice, citing Borca's view of the bog and marsh as 'wild, uncultivatable places ... "other", beyond the reach of human control' (cited in Aldhouse-Green 2002: 113). The concept of 'draining the bog' still stands for a clearing away of undesirables and the transformation of the moss was a metaphor for colonial rule and the rational 'improvement' not merely of agriculture but of a social and religious kind. The cutting of the turf, it was hoped, could literally and metaphorically remove the 'burden' of history to create a new, mutually wrought political and cultural reality (Kavanagh 2019: 70-1).

In Ireland, this discourse had a nationalist tone, but its moral tenets can also be seen playing out in miniature on Ashton Moss and Lindow Common. The far north of Ashton bog was already known colloquially as the 'far-end-o-th' world' (Higson 1859: 10; see also Figure 4.4), and the moss itself was a 'a quagmire' that Butterworth (1823: 87) hoped could, through 'judicious draining, be converted into arable land'. Its people were likewise intractable, ridiculed by Higson (1859: 33) as 'Little Moss gawbies' who were insular and tightly knit: '[They] refuse to associate in their recreations, and seldom if ever intermarry. There is a sort of clanship amongst them; they court the friendship of few outsiders, and if you offend one, you offend all.' Gossip and antagonism fuelled their everyday lives: 'the feats of renowned mowers and reapers, the death of a cow by murrain or milkfever ... political and religious animosities - furnished themes for a converse or motives for a fight' (Higson 1859: 56). By the mid to late nineteenth century, the Ashton Weekly Reporter mentions Ashton Moss mostly in relation to brawls, muggings and boxing matches, illicit liaisons and even the occasional murder. Its reputation worsened.

On Lindow, a piece of 'local' anthropology was undertaken by Norbury in 1885 , motivated by the scale of cutting on Chat Moss and cultivation on the common: 'in a few years all that can be said will be - "This was once Lindow!" (Norbury 1885: 61). It was a prescient fear, given our knowledge of the vital role these wetlands served; in his lifetime, Norbury (1885: 62) witnessed the shrinking of Lindow by half, and this, he estimated, was a mere quarter of its original extent. The watercolour section that precedes his article shows a depth of fourteen and a half feet of bog left in 1885 (Figure 4.1b). Norbury's article covers its origins and topography, but his opinion of its inhabitants speaks volumes: the bog was, he reckoned, the place where the aborigines in our colonies were pressed back to [the] worst parts of the land - the commons and the bogs' upon the arrival of successive conquering peoples (Norbury 1885: 68). Norbury (1885: 70) suggested he could 'point out not a few cases' of 'intermarriages ... between Commoners' where the characteristics of this aboriginal folk were even now, 'strongly marked'! While their self-sufficiency and ingenuity in use of bog resources impressed him, their physical and cultural character did not:

They are of a very ancient race, totally different from surrounding people ... They have the long head (Dolicho-cephalic), projecting eyebrows, high cheek bones, strong and coarse limbs, leaden aspect, slow motions, and ... the Moorish skin ... They were often buck-stealers, poachers, and fishers ... They were sly and very 
suspicious, as aboriginal race always are; apparently very harmless, but not so safe as they appeared to be. When exasperated they fight with anything that lay next them ... I may add that they in a general way shunned society, and appeared almost destitute of religious instincts. (Norbury 1885: 71-2)

Norbury might as well have been writing about the Ashton skull - his language is that of the craniologists writing about the Celtic populations of Britain (Morse 2005) and his study comparable in intent to that undertaken by Duckworth and Shore using the Ashton and Droylsden remains in 1911 - looking for a common racial type among the 'bog heads' they had procured. Norbury (1885: 73) was right about one thing: these people were no doubt 'driven to the bog', but not in prehistory - this physical and cultural marginalisation had everything to do with the disenfranchisement of the poor by enclosure, the rippling effect of the industrial revolution and the overdevelopment of rural settlements, creating suburbs for the city (such as Alderley Edge, by then in commutable distance for Manchester's 'cottontots', see Prag 2016). Norbury (1885: 74) assumed these ancient peoples had stayed put on their ancestral lands, tied to their own parish by the Poor Law. Yet as Hyde and Pemberton (2002) have shown, the moss community was remarkably permeable, taking in displaced families who believed they could claim a piece of the commons for their own; cast-out soldiers returning from the Crimean War and the First World War, joined later on by sand diggers and turf cutters (many of whom were Irish) employed on the bog as more commercial forms of exploitation took hold. Collectively known as the 'bog warriors', they erected small dwellings and bothies: fringe communities (like Blairdrummond's moss lairds) settled on land of little value, hoping to scrape by.

'Improvement' did not end with enclosure: the demands of making a living turned the bogs into commercial enterprises that saw hand cutting supplemented by light bog 'railways' before large-scale cutting machinery took over on Lindow. Though it never achieved the scale of Irish bog cutting by Bord na Móna, it was during such work that the Lindow bodies were found. Now, the desire to rewet the bog as a pressing environmental solution and thus cease peat cutting (e.g. Keddy et al. 2009) is being balanced in the planning process against the growing demand for housing at its edge. Compromises have to be made (Transition Wilmslow 2019) and these landscapes are in flux (Andersen et al. 2017). Recent applications to extend cutting at Chat Moss were sensibly refused on environmental grounds, but Askham bog on the edge of York is still under threat. The market-garden landscape of well-drained moss on Ashton-under-Lyne depicted in the Preface would have been unrecognisable to its prehistoric and later medieval inhabitants, but even that vista has now gone. Denaturation, drainage and reclamation on an unprecedented scale have turned the moss into an obdurate area of wet, rough pasture, bisected by the concrete sweep of the M60 and fringed by Ashton's sprawl of pubs, outlets and warehouses. It is we who have made it, once again, marginal.

In conclusion, the bog was uncanny and dangerous (Asingh and Lynnerup 2007: 274): not just a liminal place but also a substance and medium for which 
(unlike the 'littoral' zone of the shore) we have no distinct term. What distinguishes the bog is that it is a zone where the character of land and water changes, and is in transition (Bradley 2017): rather than being one kind of landscape it is many - always in flux, shading into different micro-locales of bog edge and depth, hummocks, pools, still points and flows (see Fontijn 2020; see also Chapter 7). McLean (2007: 62) thus sees the bog as a creative place: a setting where traditional contours dissolve and new configurations of matter might emerge. It fits well with Anderson's (2009) notion that 'affective atmospheres' are most powerfully generated where there is a tension of presence and absence, and of the insubstantial and the material, which generates turbulence - a charged atmosphere. We move closer here to an understanding of why these were such culturally meaningful places in prehistory. Yet as the above review reveals, our view of the bog is shaped in the main by the pejorative vision of non-bog dwellers, grounded in the Mediterranean eye of the classical authors - distastefully viewing a wet, intractable land they could not map or tame, witnessing interactions with the bog they could not fathom. It is further shaped by the eighteenth and nineteenth centuries during which the bog stood metonymically and metaphorically for wider ideas about race, religion, ethnicity and nationalism. These mosses would not feature so strongly in a narrative of improvement if there were no contest over them. And so it is to the value of peat as a fuel and the 'turf wars' of enclosure, allotment and drainage that we must turn, to begin to see the bog differently and recognise the wealth it held for prehistoric peoples.

\section{Turf wars}

Turf burns more slowly than timber, with an aromatic smoulder. The top surface of poorly humified peat must be discarded for it burns wet and smoky (Godwin [1981] 2009). Known as 'scraw' or 'fum', it is cut off and laid at the foot of the peat bank to encourage regrowth (Glassie 1995: 475; Robinson 2007: 59; Crawford 2018: 64-5). It is the denser, purplish-brown peat that is sought for fuel, described by Godwin ([1981] 2009) as having the consistency of cheese! In Scandinavia, a layer of reddish, very fibrous Sphagnum peat is often found towards the base of the bog: known colloquially as 'dog flesh', it is also too poor to burn, but it was in such a layer that Tolland Man was found (Fischer 2012: 39). The cutting of the turf had its place in the year, usually during May and early June (Fischer 2012: 13) and Glassie's (1995: 474) peat-cutting ethnography records that it takes at least three people to cut the bog - 'one cutting, one liftin, one wheelin'. It thus brought together not just family but neighbours: forming close bonds between households in the cycles of cutting, drying, turning and clamping or stacking on the bog, before could it be carried in the creel, cart or wheelbarrow to bring home. Early depictions of this work, such as Turner's 1808 Peat Bog, Scotland and Van Gogh's 1883 Women Working on the Peat Moor (the sketch for which is produced in Figure 4.5), capture the back-breaking labour of this work. Yet there was pride to be had in the 


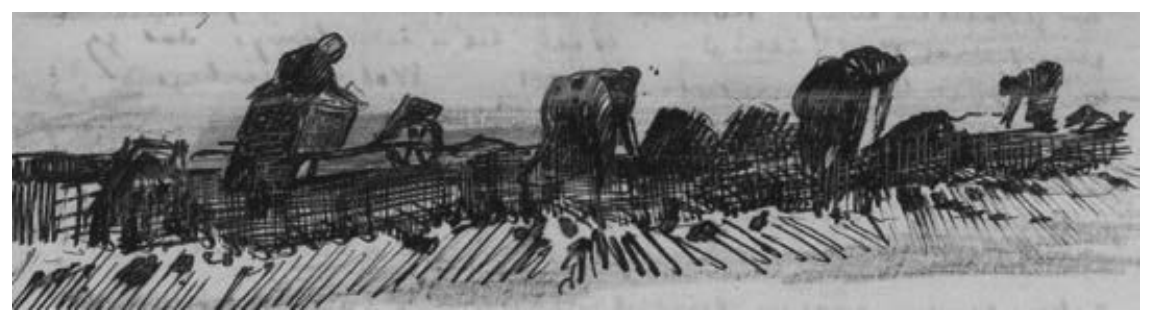

4.5 Excerpt from letter from Vincent van Gogh to Theo van Gogh with sketch of Women Working on the Peat Moor, Nieuw Amsterdam, c.7 October I883, pencil, pen and ink on paper b0354VI962r,Vincent van Gogh. All rights reserved and permission to use the figure must be obtained from the copyright holder.

rhythm and skill of this labour (Glassie 1995): Heaney (1999: 3) was not the only one to love 'the textures of the bog banks after the spade had done its work in the turf-face. Finally, there was the building of the home stack: an outward symbol of good household provision and the labour it could muster. On Lewis, the herringbone' patterns of alternating sods mimic the weave of a tweed (Crawford 2018: pl. 17), as both echo the delicate chevrons formed by a herring's ribs: a fitting reminder that fish and fuel were part of the very fabric of life.

When did cutting peat for fuel begin? A few days before the discovery of Tolland Man, the Højgaard family who found him quite literally 'turfed up' something else: a wooden implement resembling a 'short sword with a transverse handle' (Fischer 2012: 15). It was photographed by press at the time (Fischer 2012: 37) but the finders did not realise its significance and it disappeared. The Højgaards later stated that two of these objects had been found within 3-4 m of the body: one very close, at the same basal layer of 'dog flesh' peat that Tolland Man had lain in, one a little further away. These observations supported a palaeoecological assessment that the body had been deposited in an old peat cutting (Fischer 2012: 22, 36). Another nearby bog body - Elling Woman - had been found with what had been described by their neighbours as a 'wooden paddle' (Fischer 2012: 37). This double-bladed implement somewhat resembles a boat paddle, but both ethnographic analogy and experimental archaeology (at Lejre Historical Archaeological Experimental Centre) has proved they are well suited to the task of peat cutting (Fischer 2012: 38). Similar paddles and t-shape spades have been firmly radiocarbon dated to the early Iron Age, such as those from Nørre Smedeby bog, which were discovered alongside small turves 'kneaded and formed by hand' (Figure 4.6). (This way of making 'mud turves' from very waterlogged peat was observed by Boate in eighteenth-century Co. Sligo, Ireland, see Rotherham 2009: 14). Palaeoecologist Treols-Smith, who later visited the location of Tolland Man's discovery, recorded two intrusive peat cuttings deep in the bog (one clearly illustrated in section in Fischer 2012: 60-1), 'filled up with later Sphagnum peat'. 


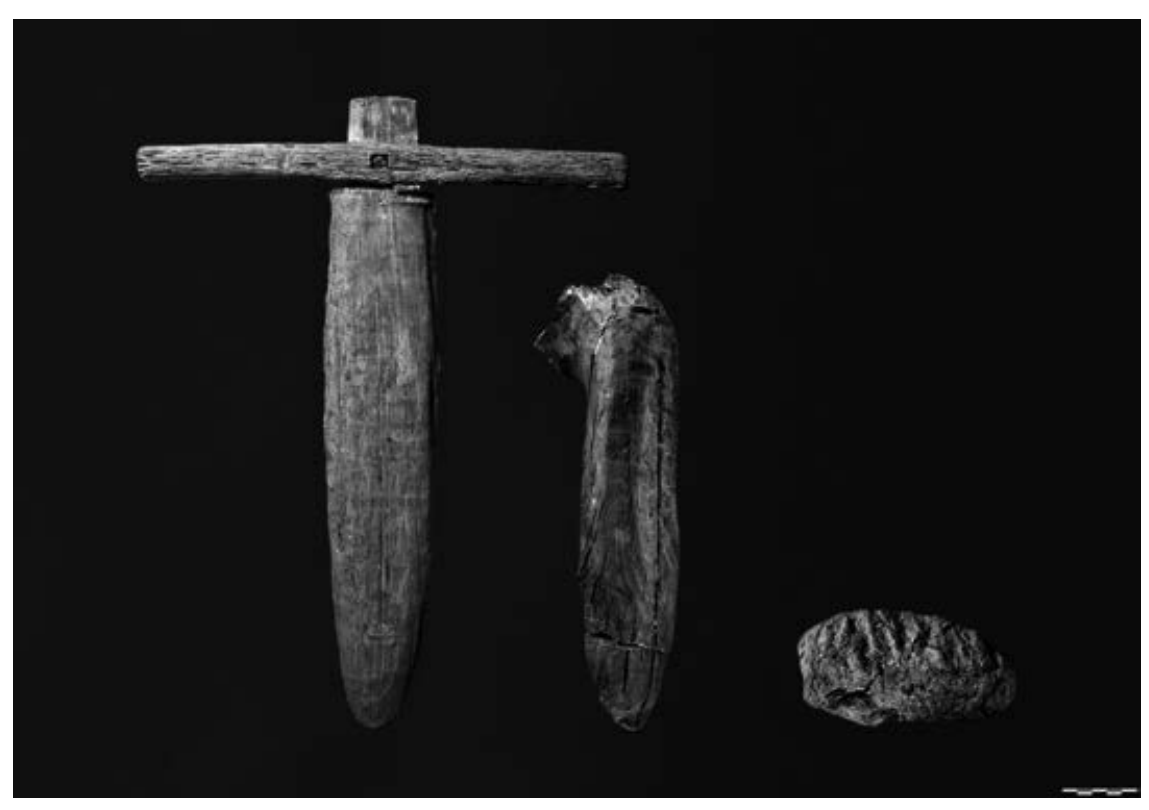

4.6 Peat spades and hand-formed turves from Nr. Smedeby, Southern Jutland, Denmark. All rights reserved and permission to use the figure must be obtained from the copyright holder.

In Denmark, cutting for peat thus began in the Bronze Age but intensified in the Iron Age (Christiensen and Fiedal 2003). In the Nebelgaard Mose bog where Grauballe Man was found, peat cutting measuring $2 \mathrm{~m}$ deep by $4 \mathrm{~m}$ across were recorded - these basins had filled up with water (Jørgenssen 1956, cited in Asingh and Lynnerup 2007: 282) mimicking the still, deep, bog pools evoked above. Borremose Woman and Huldremose Woman are also thought to have been placed in old peat cuttings (Asingh and Lynnerup 2007: 331 n. 12), while van der Sanden (1996: 35) notes that 240 of the t-shaped spades had been found in Denmark alone. Iron Age houses in the settlement of Bjerre were heated by peat fires (Asingh 2009: 176). The cutting of peat for turf is alluded to in Pliny's first-century AD account of the Teutonic tribes of the Netherlands/north Germany who 'dig up the mud which they dry more with wind than with sun, and using earth as fuel they warm their bodies, frozen stiff by the north wind' (cited in Mayhoff 1906: Bk 16: I). The area referred to includes that of the manmade terp region, where settlements were artificially built up in wet coastal and salt-marsh zones, through a mixture of 'clay, dung and organic waste [which] was highly fertile and could be used to improve the fertility of sandy and peaty soils' (Nieuwhof 2015: 19). The southern edge of this region fronted on to the bogs of the Netherlands, around Drenthe, where peat was probably cut for fuel (Nieuwhof 2015: 39), and we will return to the extraordinary range of artefacts found there 
in the following chapter. A remarkable example of where these two themes come together is the Iron Age site of Fuglsøgaard Mose (Denmark) where a relatively small bog $(200 \times 100 \mathrm{~m})$ was punctured by two 'bathtub-shaped peat cuttings' (Asingh and Lynnerup 2007: 282-3, fig. 7). Into the empty hollow (from which the fuel had been removed) were placed a series of 'votive' offerings - pots containing food, butchered remains of animals (including horses) and the tethering posts and clubs perhaps used in this sacrificial act of thanksgiving. A further thirty-eight cuttings have been identified by further survey (Bradley et al. 2015: 312). At Nørre Smedeby too, some turves were left in the base of the cutting, with pots, wooden dishes, peat spades and a plough left in the void where fuel had been cut (Bradley et al. 2015: 282). When something was taken from the bog, something had to be given back.

Evidence for prehistoric peat cutting in the British Isles is well attested in the northern Isles. A fossilised pyramidal peat stack (known in Gaelic as a 'cruach') dating to the Bronze Age was found at Balnabodach on the Isle of Barra (1690$1490 \mathrm{cal} \mathrm{BC}$, see Branigan et al. 2002: 849). Fourteen turves, most bearing pinched finger-and-thumb impressions, had been loosely stacked, with evidence for a second abandoned stack nearby. The peat had been cut horizontally 'into' an open face rather than down from above (a mode of cutting shallow peat still recorded in Caithness in 1812, see Rotherham 2009: 38). Tool marks from the rounded end of a blunt instrument $3.8 \mathrm{~cm}$ in width could be clearly seen in section. Peatcutting tools are known from other Bronze Age sites in the Hebrides (Jarlshof and Clickimin, Branigan et al. 2002: 854), while good evidence for Iron Age activity was found at the stone-built wheelhouse of Kilphede (South Uist), where a small stone cell had been used for stacking peat fuel that also bore cut marks and a 'peat spade' made of a deer shoulder blade was propped nearby (Branigan et al. 2002: 854). From the undated crannog at Lochlea (Ayrshire, probably falling into the late first/second century AD) comes not only a double-bladed 'paddle' almost identical to those from Denmark (Munro et al. 1879: fig. 86, related by the excavator to later finds of a dug-out canoe) but an extraordinary, long wrought iron implement (beautifully twisted, hinged, with three long prongs and ring attachments) interpreted as a 'moss rake'. Other Iron Age evidence for the cutting of deep peat has been reported at the broch of Upper Scalloway (Shetland) with peat ash preserved at the Ness of Gruting (Shetland), Dun Bharabhat (Lewis) and Dun Vulan (South Uist, Branigan et al. 2002: 854). At Cnip, an iron 'spade shoe' (for turning over turves) was discovered, while the ongoing excavations at the Cairns (a complex broch site in Orkney) are revealing a rich range of peaty associations including turf fuel ash around hearths, while collections of iron bog ore have been gathered and used in ritual 'closure' deposits at the end of the broch's life (Carruthers pers. comm.). To these finds from the Highlands and Islands we can add the evidence of peat as a possible fuel, preserved in burnt and unburnt fragments ('possibly from turves') in the later fill of an Iron Age roundhouse gully at Carberry Hall Farm (East Riding, see Jaques et al. 2002: 6). Macrobotanical remains of bog species, pinewood and insects suggest the cutting and use of peat 
for fuel in both hearths and ovens, possibly from the first century AD but at least from the late third to early fourth at the late Iron Age/Roman settlement at Thwing (Ferraby et al. 2017: 186-7). This material must have been brought quite a way on to the chalk Wolds, from the vales of Pickering or Holderness, perhaps holding a special value above the local timber (Ferraby et al. 2017: 186-7). Tantalising hints as to peat working in Lancashire and Cheshire exist: Charles Roeder (1901) records that a perforated limestone hammer, oak 'paddle' (reminiscent of the Danish peat tools) and clay net-sinker were found on Danes Moss, near Macclesfield. Even though we cannot trace the association between British and Irish bog bodies and peat cutting as closely as in Denmark, the need for peat as fuel clearly drew many Iron Age communities into the bog.

The peat was a source of curiosity to some of the earliest traveller-diarists from the south; sometime between 1539 and 1543, Leland recalled seeing 'pooles ... where greate plen[ty of turves] and petes hath bene diggid' (Toulmin Smith 1964:2) and how his own host at Morley Hall (Cheshire) 'brennit [bringeth] al turfes and petes for the commodite of mooses and mores at [hand]' (Toulmin Smith 1964: 3). The cutting of turf grew in popularity during the medieval period when the land itself was more rigorously charted, described and owned. 'Common rights' to the bog now fell under manorial control, defined as either 'appendant' (related to land ownership) or 'appurtenant' (related to ancient cottages, see Rotherham 2009: 43). 'Turbary-rights' (turvery) over village 'waste' completed those of pasture, piscary, estover and firebot rights to gather fuel, extract minerals or mine stone. All were jealously guarded, fuelling dispute. For example, around 1400, Sir John Assheton and Sir John Byron quarrelled over the exact boundary in the 'meres' between their lands and rights of both pasturage and peat grounds. The Black Book of Clayton (cited by Bowman 1960: 45 as manuscript 73 of the Towneley collection) reveals that many 'offensive sallies into Aston Manor, and spasmodic fights' took place (cited in Bowman 1960: 45). Finally, the Manorial Court summonsed them to 'meet upon the Moss' around 1425 (cited in Bowman 1960: 43-5). The Inquest reported that 'ther fell such words betweene the two knights' that no agreement could be made - the courts looked to memory to solve the dispute: 'old men weren sworne upon a booke' before describing the supposed boundary, which both parties then walked: 'fro osell birch to a black stake that stood in the Mosse, and fro that stake to a lach that rennes out of the mosse to a clough' (cited in Bowman 1960: 44). The inquest 'examynet Wilkyn of the Birches, a man of three score and sixteen years old' who reported where the tenants had customarily 'dolfen their turfes' and to which manor and church 'the foles, calves and lombur that have been folet, calvet and eyvet upon the more' belonged (cited in Bowman 1960: 44). Other marks featured in the dispute: the 'queche pitte' that 'lyes next to the mere-hede as the water shedes upon the more ... the black gate there' and the 'Croket birch'. I have quoted from this dispute at length because it tells us of the kind of features that helped negotiate rights at the edge of these mosslands, surrogates for which might be detectable in the bog figures raised by Iron Age trackways (Chapter 5). Sir John Stanley was tasked to resolve it 'as far as his witte stretched'; fines and 
recompenses were made (including the 'tersill of a goshawk' and 'a Hoggeshead of wine', cited in Bowman 1960: 45). New ditches were dug, and other 'markes more redy upon the ground' but Sir Stanley ensured that the 'Drye hill lye open for evermore, noght to be enprovet ne encloset; that the parties etc. may have ways ... to carry turves' (cited in Bowman 1960: 45, my emphasis).

Not to be improved or enclosed. This phrase was telling for as both processes took effect, traditional turbary plots were taken in, managed or sold, and others given in recompense as commuted rights (Rotherham 2009: 43). Others sought to sequester land to their own benefit: one Edward Walker 'had taken in a Large piece of Moss Ground' at Little Moss near Ashton in 1686. He was ordered by MossReeve that he 'must hinder noe person' in their laying out of peat and carrying it from the moss ... indeed, he was ordered to make 'a good sufficient platting and Yate' (bridge and gate) to improve their egress from the bog. Improvement of drainage, however, created good rough pasture and in 1622, 'manie reprochfull words and mad affray' arose over 'Catell in Trespassinge upon linden mosse in treading of their neighbors' turves' (Bowman 1960: 47). Disputes related to enclosure affected many of the bogs: at Theolemoss (White Moss) in 1575 it led to mass trespass and violence and the rioters 'pull[ed] up' the great gates that had been erected and made a gallows out of it (Crofton 1907: 49), perhaps intending to intimidate the would-be enclosers! On Lindow Common (east of Lindow Moss), after what was probably a bog burst in the late 1700s, those with 'moss rooms' had laid them dry through drainage and the peat was no longer being cut. By 1844, a lengthy dispute arose over illegal 'encroachments' on the common who were not paying their rents: one complainant, John Comberbirch was later named as a key offender in this localised land grab (Comberbirch 1847; see Merrill-Glover, forthcoming). Other disputes related to the private selling of turf (depriving the lord of his due) and in 1686, on Ashton, a twenty shilling fine was set after 'severall persons ... set the Moss on fire ... either by taking tobacco or otherwise' (Crofton 1907: 49): an incident all too familiar to the contemporary residents of Stockport and Manchester, as in the Pennine Moor fires of 2018. These stories remind us of the wealth of the bog as seen by those who used it, but by the nineteenth century, Butterworth (1823: 87-8) noted that only 'the surrounding poor cut turf ... [it] supplies them with fuel, during the inclement season of winter'. In 1867 the Ashton Weekly Reporter, and Stalybridge and Dukinfield Chronicle still advertised 'Patent Fire Lighting Peat' to be had from ginger-beer seller George Bowker on Mill Street: 'far cheaper and better than firewood'. But in most parts of northern England at least, as improvements were made to fire grates and chimneys and shipping by sea or canal, neither peat nor wood was needed for anything but kindling - coal had come.

The historic period thus witnessed a mapping of turbary rights and contests that have been reviewed above to help us understand how our image of the bog has been formed and to remind us that people fought over its fuel. This friction could be rightly considered anachronistic for later prehistory. However, Kelly (2006) has recently proposed that the find-spot of many Irish bog bodies falls uncannily upon 
early medieval 'barony boundaries'. It may be coincidence; the bogs of course provided the perfect watery threshold along which to mark a junction between territories and estates, just as rivers, ridges or roads might be used elsewhere. The notion of these as survivals of Iron Age boundaries must be treated with caution but we should not rule out the idea that there may have been contest over the bog. More lay in it than peat.

\section{Bog wealth}

In their study of the people of the wetlands, Coles and Coles (1989: 152) note that the 'bogs were more obstacle than a benefit, and yet they were entered, utilised ... a vital part of the life of societies living near'. What drew them there? Peat bogs tend to be characterised by less diverse vegetation than fens with their carr woodland (Godwin [1981] 2009: fig. 2), but on the blanket bogs of the British Isles and Ireland can be found heathers and ling, useful for bedding, flooring, roofing and fuel for the hearth (as demonstrated in Roman phases at Thwing, see Ferraby et al. 2017: 191). The absorbent and antiseptic properties of Sphagnum moss have long made it a favoured litter for animal bedding, which was thereby enriched to become valuable fertiliser; peat was extracted at a commercial scale for this use by the British cavalry during the First World War (Rotherham 2009: 47). Heather also provides tender young shoots that attracted grouse and ptarmigan, as do the fruiting plants of crowberry, cloudberry and bilberry (Godwin [1981] 2009: 7). The latter two berry-bearing plants are edible by humans. Bog cranberries, high in nutrients, are traditionally considered useful for treating cardiovascular and urinary complaints and have been used for dyeing but also as a poultice to treat wounds (Neto and Vinson 2011), perhaps due to their bright-red association with blood. Bog myrtle or 'sweet gale' has been used as a bitter flavouring in beer since the early medieval period at least, with other uses as a fragrant bedding agent for repelling insects and also a food preservative (Godwin [1981] 2009: 101), though some nineteenth-century herbalists warned of its 'abortive' danger for pregnant women - that too, had its place, in the herbalists' lore.

The protective power of bog substances has already been mentioned in the use of Sphagnum moss as an absorbent and antiseptic wound dressing, still in demand in the First World War (Chapter 3). It was also extensively used for sanitary 'napkins' as they were euphemistically called. It is possible this material was also gathered in prehistory for a similar purpose: Godwin ([1981] 2009: 70) cites the discovery of a mass of Sphagnum palustre on the chest of a Bronze Age inhumation at Ashgrove, Fife suggesting it might have been used to staunch a wound. In his 1657 Herbalist's tract Natures Paradise, Coles described the many different properties of moss, ranging from its cooling and binding qualities (particularly for staunching or curing bleeding from any organ or orifice), pain relief, cough cure, sleep aide and general restorative. 'Hot peat' or 'moor baths' were advertised across England and Germany between the mid-nineteenth and twentieth centuries, as 
both a healing and therapeutic skin treatment (Rotherham 2009: 47). Moss was used to treat burns and scalds, mixed with butter (Jephson 1671), or as a remedy for sleep, infused in white wine and sugar (Anon. 1675). Moss 'powder' (made from an infusion with rosewater, dried in a 'chafing dish' of glowing coals, see Anon, n.d.) provided an alluring perfume for the skin. The bog also supported many other plants used in traditional herbal medicine, pioneered in Lancashire by individuals such as Joseph Evans, the 'Boothstown Botanist' and 'herb doctor' from Worsley (Secord 1994), who were themselves drawing on centuries of medicinal tracts and recipe books (S. Handley pers. comm.). Cotton grass, purple moor grass and deer grass colonise higher hummocks, while sedges, bog asphodel, butterworts and sundews occupy the wetter and more marginal zones. Cotton grass was used to treat a range of throat and fever-related illnesses, whereas the bog violet also known as butterwort (the 'fat' plant or 'lard herb' in German) was thought to have magical properties, particularly related to protecting milk and butter from evil. It is in fact a good curdling agent, used in Scandinavia and among the Sami to make fermented milk products. Butterworts and sundews occupy the wetter and more marginal zones of bogs. These latter two plants are carnivorous, closing up their sticky leaves upon insect life that happens to light upon them, while the bladderwort uses its bristles to attract and trap insect life from the surface of the water, sucking it into the tiny vacuums formed on its leaves (Robinson 2007: 28). These seemingly merciless plants, greedy for flesh, have been used by many authors as a metonym for the moss: a microcosm of how the bog swallows land, stock and people. Yet to botanists, these are small, adaptive marvels, able to thrive in mineral-poor environments.

They need to be seen with a different eye - the educated eye perhaps, of Edward Hobson, who strode the bogs around Ashton-under-Lyne, at the turn of the nineteenth century, hunting for examples to populate his A Collection of Specimens of British Mosses and Hepaticae Collected in the Vicinity of Manchester and Systematically Arranged with Reference to Muscologia Britannica, English Botany \& c., \& c., \& c. (1818-23). This three-volume work, of which only eighteen copies were reputedly made and 'printed' in Manchester, is part flower press, part collection and part reference manual. A self-taught man, working as weaver and grocer, Hobson set out to materially evidence the full range of mosses and liverworts found on north-western bogs, progressing from the well-known (vol. 1) to the rarer examples (vol. 3). The sheets of each volume are not bound: being arranged loose-leaf by genus and species, indicated by small labels printed in Latin. He clearly gathered samples not just of each characteristic stem or frond but the capsules that release the spores of these plants. One page catches the eye (Figure 4.7): a particularly tall set of stems, some of them ending in a small russet 'purse'. This is Polytrichum commune: known colloquially as 'common haircap', 'golden maidenhair', 'great goldilocks' or 'hair moss'. By the medieval period, an infusion of this moss was believed to strengthen or beautify the hair, perhaps through a form of sympathetic magic, for its luxurious stems grow up to $30 \mathrm{~cm}$ in height (and, rarely, up to $70 \mathrm{~cm}$ ) topped by the vivid golden-amber capsules when 


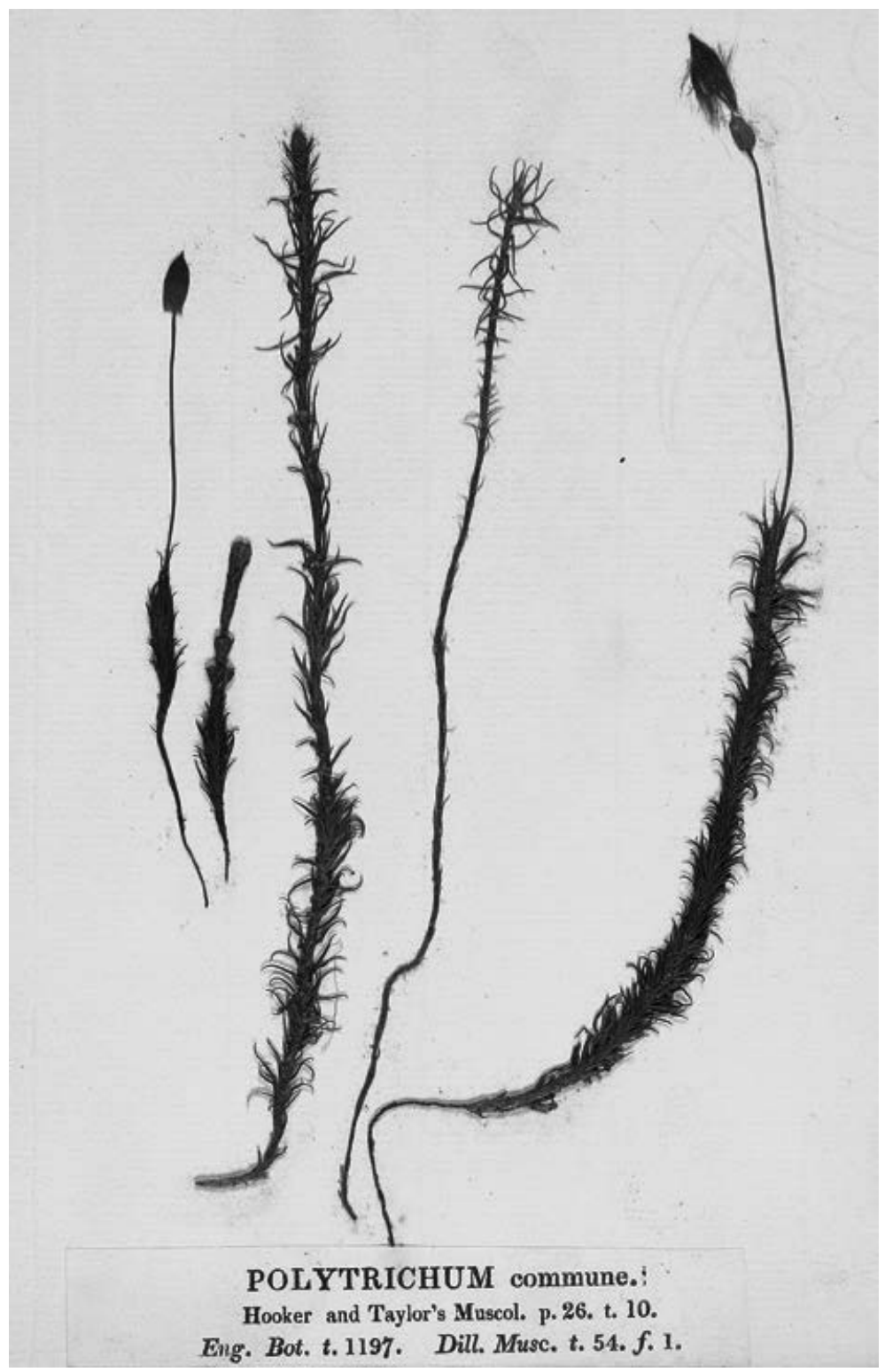

4.7 Polytrichum commune from A Collection of Specimens of British Mosses and Hepaticae Collected in the Vicinity of Manchester, vol. I. All rights reserved and permission to use the figure must be obtained from the copyright holder. 
in spore (described also by Coles (1657: 34) as an effective tonic when ingested for all manner of stomach ills). Apart from this beautifying or medicinal property, it has another use. In one of the glass cases at the Roman fort of Vindolanda, perched on a stand, is a remarkable head covering woven from hair moss, described as a 'cap' (Figure 4.8a). Blackened by the peat in which it was buried, its detailed analysis by the textile expert John Peter Wild (1994), revealed that it was woven using basketry skills: a hollow 'top knot', under which projects a cap of dense and skilfully woven 'rands', ending in a projecting fringe of $c .28 \mathrm{~cm}$, which would have come down to the nape. It does not appear to be a wig, although a helmet crest was recovered from the same site (Figure 4.8b). It dates to the early phases of the fort's occupation - only twenty years or so after the conquest of northern

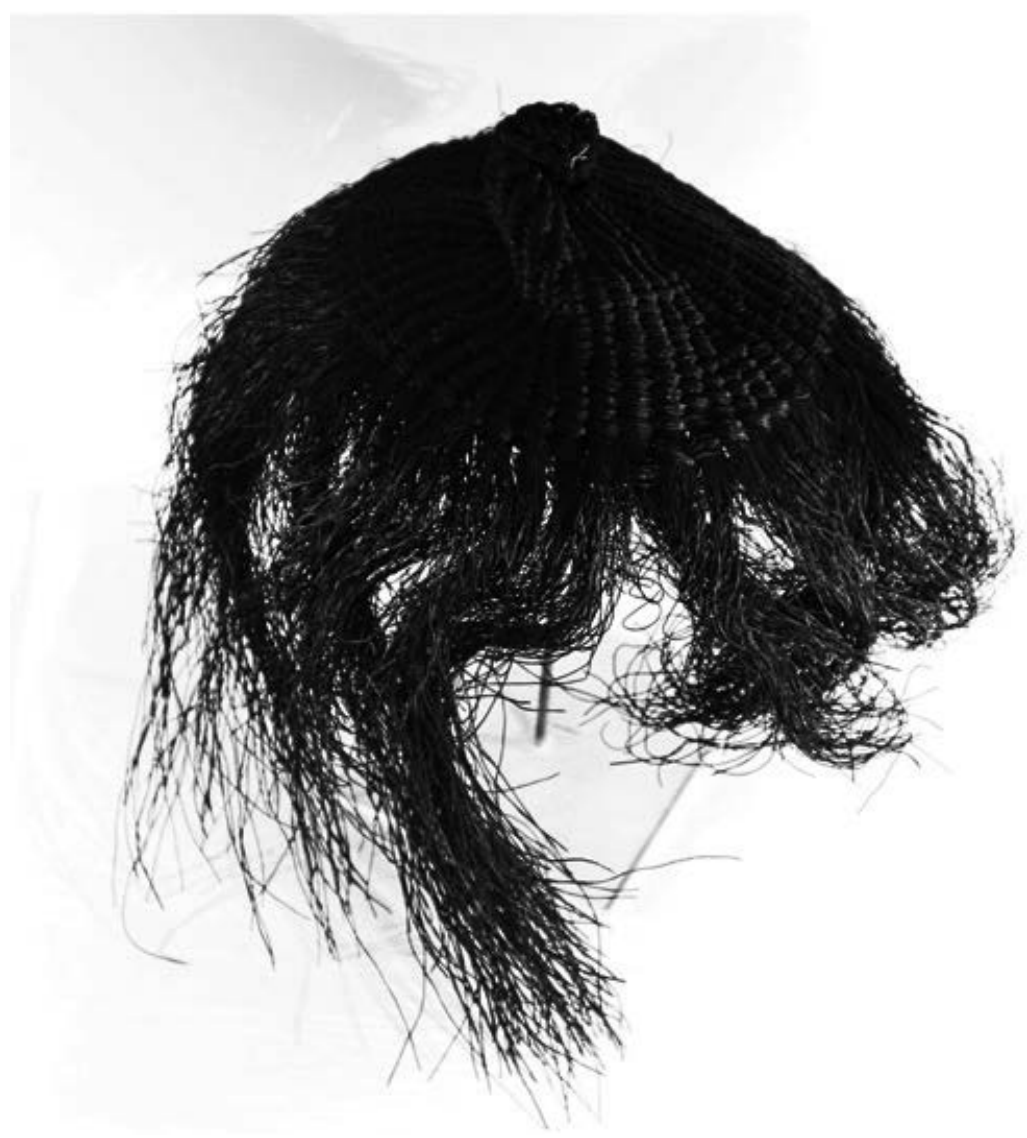

4.8a The Vindolanda 'cap', made from Polytrichum commune, from Vindolanda Roman fort. All rights reserved and permission to use the figure must be obtained from the copyright holder. 


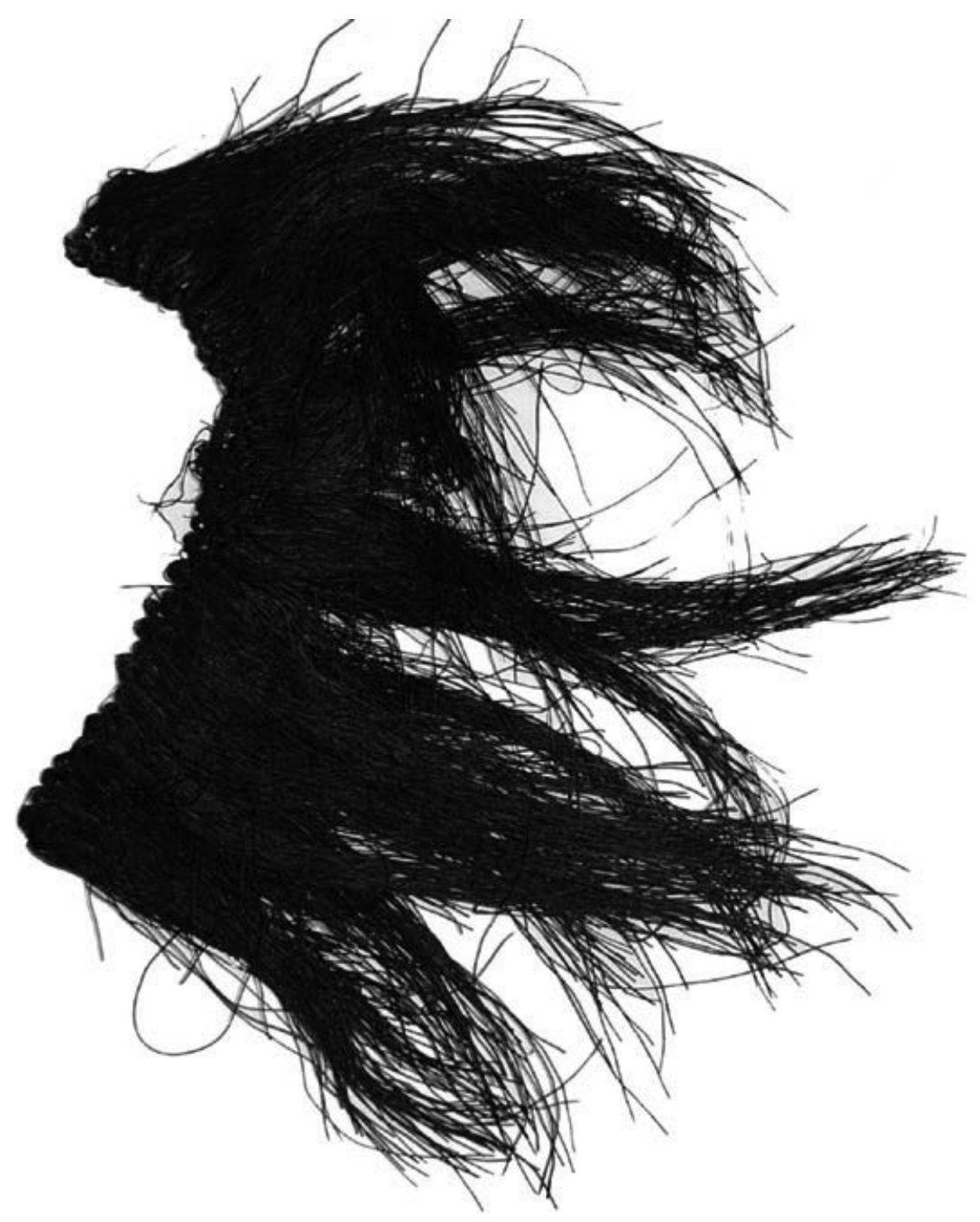

4.8b The Vindolanda helmet 'crest', made from Polytrichum commune, from Vindolanda Roman fort. All rights reserved and permission to use the figure must be obtained from the copyright holder.

Britain - and there is a near parallel from Newstead, suggesting this was not a unique object nor a Roman one, but that it should be situated within a wider late Iron Age tradition of organic head coverings (Wild 1994: 64). Several worked 'fringes' or 'pig tails' made from the same species Polytrichum commune, as well as a folded bundle of semi-worked, plaited stems were found at Lochlea crannog 
(Munro 1879: fig. 109). Humorously, but perhaps insightfully, Wild suggests that this fringed and waterproof cap would certainly have proved effective against the most insidious of Scottish enemies: the midge.

Moving on to animal life, at the edge of Ashton Moss, 'Snipe Tavern' still evokes the drumming warble of this common wetland bird, while Higson (1859: 80) lamented the killing of the last booming bittern (once 'an esteemed delicacy') as part of the final enclosure of the bog. The rich insect life (purple-bordered gold moths, heath butterflies, bog bush crickets, mire pill beetles, black bog ants, large marsh grasshoppers) found on the north-west wetland bogs once fed a variety of larger animals such as the common frog (English Nature 2002). A recent survey of Astley Moss reported up to ten species of dragonfly haunting and hunting the hummocks of the bog, alongside short-eared owls, water voles and merlins in winter (Lancashire Wildlife Trust 2019). Badgers, foxes, stoats and otters can also be tempted on to the bog to hunt or to cross between habitats. The role of the bog as a 'trap', either for the unfortunate Mobberley boar, other large game or domesticated stock, has been well discussed. Norbury (1885: 71) notes that the Lindow folk were notorious 'poachers and fishers', though fish cannot survive in the acidic, oxygen-excluding environment of the peat bog itself, in contrast to the richness of the fens (renowned for its eels), meres and marshes. Leigh (1700: 19) boasted that 'great Quantities of Fish, as Roach, Eels, Pikes, Pearch, Breams' could be had in Martinmeer, for example. Bird life enlivens the apparently sterile bog: flycatchers, marsh tits, linnets, reed buntings and willow tits are among the smaller birds that would have been seen, heard and perhaps netted, while nesting species included the golden plover, the dunlin and the red-throated diver. Birds of prey such as hen harriers are also attracted by the smaller bird life on the bog, and seasonal migrants might alight there, en route to more permanent wetlands, encouraging seasonal fowling. Domestic peat cutting, especially the creation of small in-filled pools, created its own micro-environment, attracting large red damselflies and other species (Robinson 2007: 65). One of the other infamous inhabitants of the peat bog in Britain was the adder, the island's only poisonous snake, which perhaps attracted more 'venom' than was fair, given its rarity. On Lindow Common, Finney recalls that a 'Viper Catcher' was paid once a year to rid the moss of these snakes, which 'sometimes occasion Mischief' (cited in Worthington Barlow 1853: 45). A boy 'had been bit by one while he was ranging after Cranberrys, of which there is great plenty, with naked feet', and Finney's own dog - a Pointer - died after such a bite to his head (cited in Worthington Barlow 1853: 45).

Both bog and bogside created a narrow but useful array of organics that lent themselves to the making of containers and traps, revealed in the otherwise pejorative ethnography of Lindow Moss by Norbury (1885). Its nearby inhabitants were 'expert in using twigs or osiers, in making besoms from birch and broom, also in making straw-work, beehives, \&c. from split briars' (Worthington Barlow 1853: 45). They were also 'very expert in making primitive traps and snares from withes and bands' (Worthington Barlow 1853: 45), a point we will return to in Chapter 6 in relation to the devices used to dispatch, bind or disable bog victims. 
Around the same era, Higson (1859: 156) wrote of Ashton Moss that its 'upper portion gains firmness and solidity ... growing rushes, ferns and heather'. The rushes did not only furnish floor coverings and basketry; in Ashton they were woven into 'rush carts' - impressive artistic constructions, done up with ribbons and flowers, which formed the centrepiece of late summer festivals. Yet it was not so much the bog as nearby woodland that would have facilitated the making of what Hurcombe (2014) calls 'the missing majority' of organic containers, vessels, utensils, implements, clothing, boats, vehicle components, personal ornaments, figures, building materials, even weapons, which are revealed in rare, late Bronze Age and Iron Age waterlogged sites in England and Scotland. Sites such as Glastonbury and Meare Lake Villages, Flag Fen, Fiskerton, Cults Loch, Black Loch or Must Farm give an insight into the mundane 'wealth' of agricultural and cultural life. Hurdles, baskets, pole-lathe turned bowls, spoons and ladles, buckets, tubs, chariot and cart components, ards for ploughing, spear shafts, balls of plant fibre, boxed-up handshears: wetland archaeology provides the richest and most engaging insight into the full realm of prehistoric craftwork (Coles and Coles 1989). In the following chapter, we will discuss what ended up in the bog, but most of these materials and objects speak of manufacturing well away from the bog environment. Stakes, withies and sprang bands, for example, often woven from flexible hazel wood, feature in a number of bog body finds (see Chapter 6), but they must have been made some distance from the violent events in which they were implicated. There were only a few direct organic craft materials culled from the bog itself. For example, Pliny notes that the inhabitants of the Netherlands 'terp' made use of some bog plants: 'with the sedge and the rushes of the marsh they make cords, and with these they weave their nets' (cited in Mayhoff 1906: Bk 16: 1).

One of the most common 'finds' from the bog listed by later authors were the preserved remains of trees, representing the submerged vegetation from the earliest phase of its transformation into a bog. Some thought these were relics of the biblical flood (cited in Leigh 1700: 89; de la Pryme 1870: 983) or else evidence of 'ye burning and chopping of ye same [trees in the moss] by the Romans' (de la Pryme 1870: 314). Norbury (1885: 63) comments on the rare 'charred stocks' found under the peat on the original land surface at Lindow. This 'bog oak' was extraordinarily durable: de la Pryme (1870: 249, letter dated 2 Feb. 1701-2) sent a sample of it to Dr Sloan, noting: 'I have put in to the box a piece of the black oak that is digged up in this country, observable for its colour and hardness'. The geologist Charles Lyell 1838: 22) also recorded that on Hatfield Moss, 'fir-trees have been found ninety feet long, and sold for masts and keels of ships'. In the hamlet of Alt (neighbouring Ashton) a farm named 'Turf Pits' was built with bog oak found resting on the underlying clays (Butterworth 1823: 6), while an oak-bog 'stock' measuring nine foot in circumference was found at the 'far-end-o-th'-world' (Higson 1859: 158). Bog oak became more popular as peat cutting expanded in the seventeenth to nineteenth centuries, being reused for construction in houses and trackways, as well as for ornamental veneers, furniture and keepsakes or souvenirs (such as the 'bog oak pendant cross' held in the National Museum in NI, Ulster, combining 
Celtic shamrock and harp with Christian symbolism). Paper made from peat was made in Ireland, and although generally uneconomical to produce, it enjoyed brief popularity as postcards or greetings cards sent to Irish emigrés (Rotherham 2009). Bog fir, meanwhile, was also renowned for its flammability, used 'by the poor in lieu of candles' (Rotherham 2009: 159). As Butterworth (1823: 88) also notes: 'Red fir trees have frequently been found in it, which being full of their once nourishing and resinous gum, when split, serve the purpose of striking a light ... besides which large oaks as black as ebony and perfectly sound, have been dug therefrom' While we have little evidence of the use of bog wood in the Iron Age or Roman period, this might be hard to identify unless multiple radiocarbon dates yielded material 'out of time' compared with its depositional context.

Finally, the bog 'grew' iron. Bacterial action in swampy conditions led to the oxidation of iron-rich groundwater, creating a precipitate known as bog ore or 'limonite' - a poor, porous iron ore that can be either rich or low in phosphorus (Crew 2013). The ubiquity of this substance and its lower melting point than purer forms of ore rendered it a favourite choice for Iron Age smelting though it brought its own challenges (McDonnell 1995; Crew 2013; Dungworth 2015). Through experimentation, it has been estimated that $8 \mathrm{~kg}$ ore can yield c.5 $\mathrm{kg}$ of slag and $2 \mathrm{~kg}$ of bloom (Crew and Charlton 2007: 222). High raw material volume to product rates and variable qualities of finished bar iron were notable (Crew 2013), though residual silicates in bog iron could have helped make finished objects more resistant to rusting (Heimann et al. 2002). Bog iron was self-renewing - it is estimated that a bog ore can regenerate at a rate of 5-10 cm a year (Tylecote 1986: 125) and thus could be 'harvested' at least once a generation. Halkon and Starley (2011: 138) also report on field drains that had become blocked by bog ore in less than a decade. Yet a direct link between a bog ore source and evidence for local working is difficult to prove, given the array of chemical signatures this material can produce and the fact that 'bog ore' is often used to refer to any alluvially deposited iron ore (McDonell pers. comm.). Fischer (2012: 157) notes that Tolland Man and Elling Woman were buried in area renowned for bog ore and in sight of Klode Mølle ('iron ingot' mill) - one of Central Jutland's main exports by the Middle Ages. One of the most extensively investigated examples is from the later Iron Age site of Yderick in Denmark, where over fifty buried slags dating between the second and seventh centuries AD represent single-use shaft furnace smelting of the local bog ore (Peters et al. 2008). A positive identification was made between slags deposited in an Iron Age pit at the Lower Lusatian Wolkenberg-26 smelting site (Peters et al. 2008: 230) and samples of bog ore from potential sources nearby. Meanwhile, on Bourtangermoor in Holland, Casparie (1986) has argued that two middle Iron Age features - a footpath and a wattle-work trackway - were designed to move ore from the bog to dryland. A worked oak plank dating to the earlier Iron Age (680$550 \mathrm{cal} \mathrm{BC}$ ) was found in association with one of the main patches of ore itself, and Casparie (1986: 180) makes a tentative association between this early phase of ore working and a major bog burst event of c.500 BC. 
In Wales, Crew (2013: 26) identified the presence of bog ore at the Iron Age sites of Bryn y Castell (with high phosphorous content) and Cracwellt (with low phosphorus content), both in Wales, alongside smelting debris, smithing tools and iron-working structures. His groundbreaking smelting experiments involving ore from both sites, along with other sources, proved (among other things) that the lower-phosphorous ore was easier to smelt and though difficult to forge both kinds of ore gave good cutting edges to blades. Actual production sites are even rarer, such as the lower Foulness Valley in East Yorkshire, where Halkon (1997, 2003; Halkon and Millett 1999) has shown how the careful management of woodland fuelled an iron-smelting industry. In Halkon's landscape study, nineteen ironsmelting sites were found in an $8 \times 8 \mathrm{~km}$ landscape block, suggesting a multiperiod use of the local bog ore, including a major early to middle Iron Age slag heap at Moore's Farm, Welham Bridge, estimated as representing over 9,120 kg of original bog ore (Halkon 2012: 105-6, pl. 17) and an undated but presumably middle to late Iron Age slag heap at North Cave, just across from Welham (Halkon 1996). This bog ore (known locally as 'nossman') is vividly illustrated in Halkon and Starley (2011: fig. 3) and was also successfully experimentally smelted by Crew (2013), although the ore was sandy and needed careful preparation to produce a relatively low-grade bloom. Crew (2013: 36) suggests re-smelting of such blooms may have been required, while even a good bog-iron bloom requires twenty to forty reheating episodes to work it into a serviceable currency bar or billet form, ready for smithing. The proximity of these smelting sites to the local Iron Age square barrow cemeteries (renowned for their iron chariot gear, weaponry and mirrors) suggests that smiths were carrying out primary production on the sandy, raised ridges close to this ore, with woodland nearby to supply their charcoalfuelled bowl or shaft furnaces. Yet as King (1685: 953-4) notes, peat not only produced 'a tolerable sweet fire', but the 'turf char'd [charcoaled] serves to work iron ... in a bloomery or iron-work'. While Halkon (2003) has convincingly identified the use of wood charcoal at Welham and wood charcoal was used throughout Crew's experimental campaign, it is possible we underestimate the use of peat-charcoal as a smelting fuel, given its convenient co-location with the ore and greater capacity for heat production (Asingh 2009: 190; Fischer 2012: 157). Diligent research into bog ore deposits on Iron Age and early Roman settlement sites in South Yorkshire reveal glimpses of bog ore use: an 'iron concretion' at Carr Lodge Farm and a curated and deposited lump of bog ore at Deepwell Mews (Chadwick 2019).

In Ireland, one of the brushwood, hurdle and plank tracks on Lemanaghan bog dated to 348-57 BC ran not from dry spot to dry, but out into the wet, close to a substantial ore deposit (O'Carroll 2001: 15). The insightful work of Dolan (2016: 35) reveals strong correspondences between sources of bog ore and shaftfurnace smelting dating to the Iron Age in the midlands, though exact sourcing is problematic. At Derrinsalagh, the clustered remains of over thirty furnaces suggests repeated, episodic small-scale working at a site renowned for its proximity to ore sources at Derryville Bog (Dolan 2016: 35). Dolan (2016: 43) points 
out the general rarity of ironworking and reminds us that it was deployed on a restricted repertoire of important objects: knives, sword blades and spears, horse gear and pendants, as well as decorative fittings of the Ballydavis composite 'box' where its tin-rich bronze lid was finished with iron roundels set with red glass. $\mathrm{He}$ urges us to consider the ways in which both smelter and smith were seen in contemporary society, suggesting that at least in Ireland, this was a restricted craft, with sociopolitical and magico-religious overtones. Finally, iron deposits were not only useful for smithing - in Roundstone bog, Robinson (2007: 106) mentions the importance of what is known colloquially as the 'black stuff': 'the intensely black, iron-rich sediment collected from the bottom of bog-holes, widely used for dyeing wool until a couple of generations ago ... it gives a dull black colour, or, with the addition of oak chips, a glossy jet black'. Iron was also a good mordant (a fixative, for other dyes), which from the bog might include the cloudberry, crowberry and sundew (yielding purple dyes) and bog asphodel and bog myrtle (yellow). It is salutary to appreciate the ways in which such different substances were mutually implicated in a range of crafts, and how the bog could feed larder, medicine cabinet and dyer's vat, supply bedding and roofing and fuel the smith's workshop and hearth.

\section{Conclusion: deep places, thin places ...}

This chapter has examined the bog, seeing through the pejorative discourse of the improvers to a rich and productive if distinctive and dangerous landscape. From prehistory onwards, people made ad hoc inroads into the mire, laid trackways and small platforms and constructed stony ways around its most treacherous pools. They came for fuel, ore, culinary and medicinal plants, bird and animal life. Accounts of turf cutting have shown how friction might arise over these resources but also how work in and around the bog helped reaffirm relations between neighbours and communities. They also came into the bog to engage in other kinds of activities: rituals involving the dead but also other kinds of offerings and performances, as the next chapter will discuss. People's dealing with the bog were part of what Fredengren (2015: 161) calls the 'geopolitics', or more specifically, 'waterpolitics' of their worlds. Like other bodies of water, it was 'socially and politically constituted' (Edgeworth 2011: 157). Yet the behaviour of the bog and phenomena witnessed there lent it an animacy that may well have amounted to what Strang (2014) has called an 'agential power'. As Fredengren (2015: 175) puts it, the bogs were a somewhat 'volatile' partner in human affairs.

I want to end this chapter with the notion that as well as being 'deep places' these were also, in contemporary theological language, 'thin places' - one of Eliade's (1963) hierophanies - where the sacred might be touched and the supernatural realm made manifest. It was a place that loomed large not just in the imagination, but the very psychogeography of its inhabitants. 
In The Beauty Things, the renowned author Alan Garner discusses with archaeologist Mark Edmonds a range of objects that he has found, or that have come to him, which have inspired ideas in his many novels and essays. He recalls how a peat digger cutting turf on Lindow Moss in the 1950s came across a curious object in the bog: 'a stone, a black stone, flecked with red, part bubbled as a brain, part rough as frost, and all stuck about with clear crystals that winked in the light' (Edmonds and Garner 2016: n.p.). Intrigued, he took it to the Manchester Museum's geology department, but they sampled it for identification purposes, much to the man's ire. They looked upon it, Garner suggests, merely 'as geology ... a lump of haematite with quartz crystals' (Edmonds and Garner 2016: n.p.). Outraged, the turf cutter passed the object on to Alan, knowing that 'he'll look after it better'. He did. In his hands this object becomes the 'swaddledidaff' of Strandloper (Garner 1996): the lucky stone that the Marton labourer, William Buckley, takes with him when he is transported to Australia (Figure 4.9). He escapes incarceration and finds himself among an aboriginal community who see a very different suite of qualities in the stone to the blunt mineralogical description above.

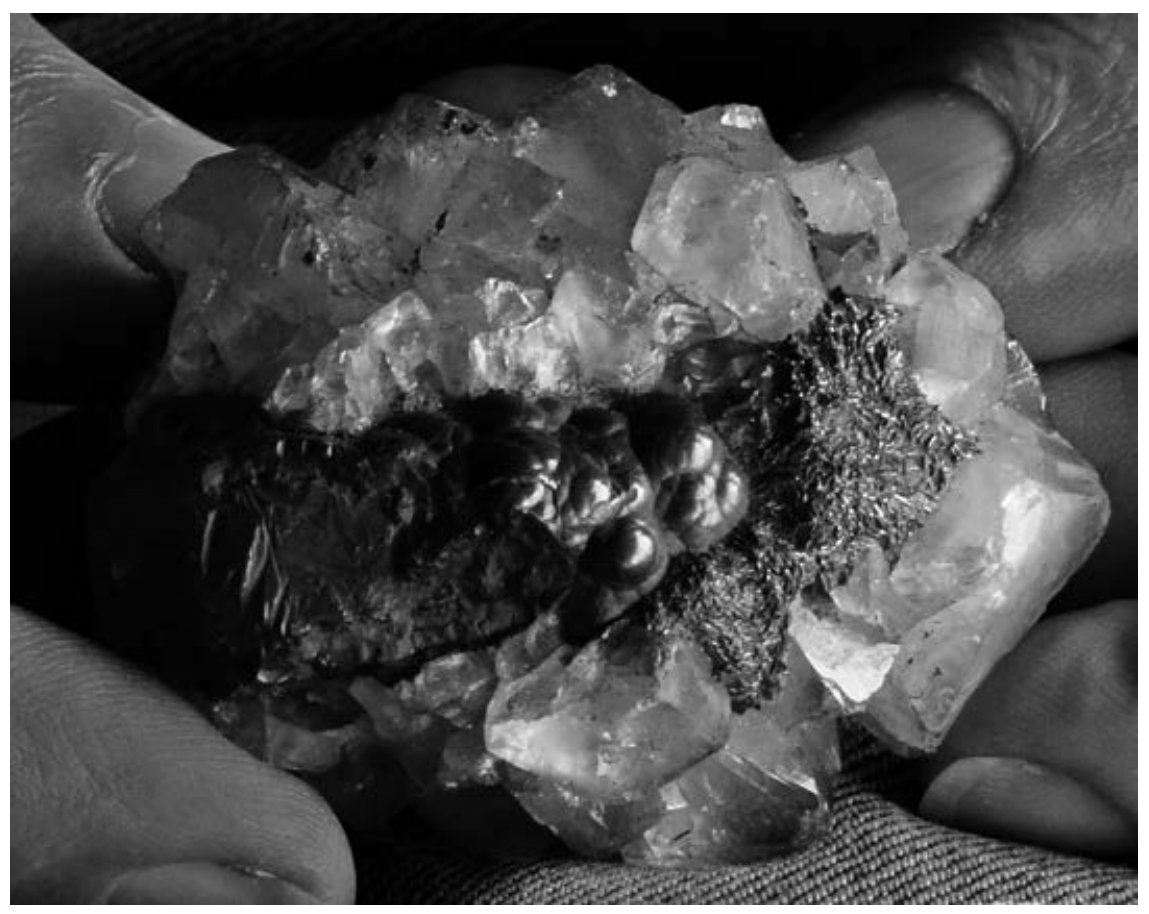

4.9 The 'swaddledidaff' - a haematite nodule with quartz crystals, found on Lindow Moss. All rights reserved and permission to use the figure must be obtained from the copyright holder. 
It does not take a man like Alan Garner to see the power of such an odd object: the turf cutter himself knew it to be something special, for this was nothing like the iron ore found in the bog. It was iron but it did not belong - not here at least. But it does take someone like Alan Garner to find the right words to conjure how this stone 'resonates' in his words, with ideas of craft, light and power, and to pose the very simple point that the museum missed - the question of how it came to be in a bog wasn't asked. Things given up, given over or given back - it is to these themes that the next chapter turns. 